\title{
Anoctamin 1 (Ano1) is required for glucose-induced membrane potential oscillations and insulin secretion by murine $\beta$-cells
}

\author{
Raphaël Crutzen $^{1}$ - Myrna Virreira ${ }^{1}$. Nicolas Markadieu ${ }^{1} \cdot$ Vadim Shlyonsky $^{3}$. \\ Abdullah Sener $^{3}$ - Willy J. Malaisse ${ }^{2} \cdot$ Renaud Beauwens $^{1}$ • Alain Boom ${ }^{4}$. \\ Philippe E. Golstein ${ }^{3}$
}

Received: 10 July 2015 / Revised: 8 November 2015 / Accepted: 9 November 2015 /Published online: 18 November 2015

(C) The Author(s) 2015. This article is published with open access at Springerlink.com

\begin{abstract}
Anions such as $\mathrm{Cl}^{-}$and $\mathrm{HCO}_{3}^{-}$are well known to play an important role in glucose-stimulated insulin secretion (GSIS). In this study, we demonstrate that glucose-induced $\mathrm{Cl}^{-}$ efflux from $\beta$-cells is mediated by the $\mathrm{Ca}^{2+}$-activated $\mathrm{Cl}^{-}$channel anoctamin 1 (Ano1). Ano1 expression in rat $\beta$-cells is demonstrated by reverse transcriptase-polymerase chain reaction, western blotting, and immunohistochemistry. Typical Ano1 currents are observed in whole-cell and inside-out patches in the presence of intracellular $\mathrm{Ca}^{++}$: at $1 \mu \mathrm{M}$, the $\mathrm{Cl}^{-}$current is outwardly rectifying, and at $2 \mu \mathrm{M}$, it becomes almost linear. The relative permeabilities of monovalent anions are $\mathrm{NO}_{3}^{-}(1.83 \pm 0.10)>\mathrm{Br}^{-}$ $(1.42 \pm 0.07)>\mathrm{Cl}^{-}(1.0)$. A linear single-channel current-voltage relationship shows a conductance of $8.37 \mathrm{pS}$. These currents are nearly abolished by blocking Anol antibodies or by the inhibitors 2-(5-ethyl-4-hydroxy-6-methylpyrimidin-2-ylthio)- $N$-(4-(4methoxyphenyl)thiazol-2-yl)acetamide (T-AO1) and tannic acid (TA). These inhibitors induce a strong decrease of $16.7-\mathrm{mM}$ glucose-stimulated action potential rate (at least $87 \%$ on dispersed cells) and a partial membrane repolarization with TAO1. They abolish or strongly inhibit the GSIS increment at $8.3 \mathrm{mM}$ and at $16.7 \mathrm{mM}$ glucose. Blocking Ano1 antibodies also
\end{abstract}

Alain Boom and Philippe Golstein contributed equally to this work.

Renaud Beauwens

renbeau@ulb.ac.be

1 Laboratory of Cell and Molecular Physiology, Université Libre de Bruxelles, Campus Erasme, Brussels, Belgium

2 Department of Biochemistry, Université Libre de Bruxelles, Campus Erasme, Brussels, Belgium

3 Laboratory of Physiology and Pharmacology, Université Libre de Bruxelles, Campus Erasme, Brussels, Belgium

4 Laboratory of Histology, Histopathology and Neuroanatomy, Université Libre de Bruxelles, Campus Erasme, Brussels, Belgium abolish the 16.7-mM GSIS increment. Combined treatment with bumetanide and acetazolamide in low $\mathrm{Cl}^{-}$and $\mathrm{HCO}_{3}{ }^{-}$media provokes a $65 \%$ reduction in action potential (AP) amplitude and a $15-\mathrm{mV}$ AP peak repolarization. Although the mechanism triggering Ano1 opening remains to be established, the present data demonstrate that Ano1 is required to sustain glucosestimulated membrane potential oscillations and insulin secretion.

Keywords Chloride $\cdot$ TMEM16A $\cdot$ Islet

\section{Introduction}

The $\beta$-cell is known to be an excitable cell for more than 40 years [15-17]. Glucose induces cyclic variations in the membrane potential which are critical for sustained insulin release. Yet, these variations cannot be all ascribed to the specific gating of well-defined ion channels unlike what is established for the membrane potential cyclic variations in the heart [4], as reflected in electrocardiogram. Insulin release requires an increase of the cytosolic calcium concentration $\left(\left[\mathrm{Ca}^{2+}\right]_{\mathrm{i}}\right)$ by any means, i.e., either from the extracellular medium or from intracellular stores. When extracellular glucose concentration is raised $(6-10 \mathrm{mM})$, $\left[\mathrm{Ca}^{2+}\right]_{\mathrm{i}}$ increase mainly results from the opening of the plasma membrane L-type $\mathrm{Ca}^{2+}$ channels which appears as bursts of spikes superimposed on repetitive slow waves of depolarization, also called active phase. When glucose concentration is further raised, the active phase is progressively extended and finally appears uninterrupted at $25-\mathrm{mM}$ stimulation [56, 81]. The earliest electrical event induced by glucose stimulation is the closure of the $\mathrm{K}_{\text {ATP }}^{+}$channel that induces membrane depolarization, the latter being reproduced by sulfonylurea drugs [28]. Glucose and sulfonylurea drugs induce long-term fluctuations of the membrane potential with a spiking activity as soon as the threshold of the L-type $\mathrm{Ca}^{2+}$ channels is reached, hence increase 
intracellular $\mathrm{Ca}^{2+}$ and insulin release which lasts as long as the stimulus is applied (at least for $1 \mathrm{~h}$ ) [29, 44, 51, 52, 62]. In sharp contrast, depolarization induced by raising the external potassium concentration results in a single sustained change in membrane potential (and $\left[\mathrm{Ca}^{2+}\right]_{\mathrm{i}}$ ) which induces only a short burst ( $\pm 7 \mathrm{~min}$ ) of insulin release, i.e., the so-called "first phase" of insulin secretion with progressive decrease toward basal insulin release $[6,32,51,52]$.

It is however well recognized that closure of $\mathrm{K}_{\text {ATP }}^{+}$channels alone is not sufficient to reach the threshold of $\mathrm{Ca}^{2+}$ channel activation. As $\beta$-cells are quite rich in $\mathrm{Cl}^{-}[9,26]$, as early as 1978, Sehlin [66] questioned whether this depolarization could be caused by a $\mathrm{Cl}^{-}$efflux as he demonstrated that glucose induces an increase in ${ }^{36} \mathrm{Cl}^{-}$efflux from ${ }^{36} \mathrm{Cl}^{-}$prelabeled mice islets. Also, severe reduction in anion efflux by incubation in low $\mathrm{Cl}^{-}$(or bicarbonate) media inhibited the electrical bursting pattern together with the ${ }^{45} \mathrm{Ca}^{2+}$ uptake, hence the glucosestimulated insulin secretion (GSIS) [65, 67]. Furthermore, Malaisse et al. [43] established that raising extracellular glucose concentration in the range of 5-20 mM increased proportionally the ${ }^{36} \mathrm{Cl}^{-}$efflux from prelabeled rat islets, thus suggesting that glucose induces the opening of some anion channel [43]. In the present study, we therefore investigated whether such chloride efflux could be mediated by anoctamin 1 (Ano1) channel, also called TMEM16A. Ano1 is a $\mathrm{Ca}^{2+}$-activated $\mathrm{Cl}^{-}$channel $(\mathrm{CaCC})$ which belongs to the "anoctamin" family of anion channels recently discovered and cloned (for review, see Pedemonte and Galietta [55] and Kunzelmann [38]). This new family of $\mathrm{Cl}^{-}$channel which shares no sequence similarity with any other membrane protein appears expressed in almost every tissue. In particular, Anol is expressed in many different secretory epithelia including the digestive tract: salivary glands, exocrine pancreas, hepatocytes, ileum, and large intestine. It also plays a major role in the pacemaker motility function of the interstitial cells of Cajal [35, 79]. Furthermore, it has also been implicated in cell migration and cancer proliferation [75]. Ano1 knockout mice die soon after birth due to tracheomalacia and also multiple organ impairment [63].

In support to our hypothesis implicating Ano1 in the depolarization critical to open $\mathrm{Ca}^{2+}$ channels, Ano1 haploinsufficient mice exhibit impaired insulin secretion [76], and the present study provides evidence that the opening of the calcium-sensitive Ano1 channel plays a prominent role in glucose-induced membrane potential fluctuations and is therefore critical to achieve a sustained insulin secretion.

\section{Materials}

\section{Chemicals}

Ano1 (TMEM16A) inhibitors T16Ainh-AO1 or 2-(5-ethyl-4hydroxy-6-methylpyrimidin-2-ylthio)-N-(4-(4- methoxyphenyl)thiazol-2-yl)acetamide (T-AO1) and tannic acid (TA) were respectively purchased from Merck Biosciences (Darmstadt, Germany) and Sigma (St Louis, MO, USA). Bumetanide (NKCC1/2 inhibitor, \#B-3023), acetazolamide (carbonic anhydrase inhibitor, \#A-6011), and poly-L-lysine hydrobromide (\#P6282) were purchased from Sigma (St Louis, MO, USA). Compounds of the different buffers were purchased from Merck (Darmstadt, Germany). Collagenase P (\#11 213873 001) and protease inhibitors (complete mini \#11 836153 001) were purchased from Roche (Mannheim, Germany).

\section{Antibodies}

Rabbit polyclonal Ano1 antibodies (ab84115) for western blotting purpose, rabbit polyclonal blocking Ano1 antibodies (ab72984, directed against the fifth and sixth transmembrane domains that constitute the pore-forming region) for patchclamp and insulin release experiments, and human Ano1 synthetic peptide (ab97423) for immunofluorescence purpose were purchased from Abcam (Cambridge, UK). Goat polyclonal Ano1 antibodies (sc-69343) for immunofluorescence purpose were purchased from Santa Cruz Biotechnology (Dallas, TX, USA). Rabbit anti-goat biotinylated antibody (BA-5000) was purchased from Vector Laboratories (Peterborough, United Kingdom). Horseradish peroxidase (HRP)conjugated anti-rabbit was purchased from Dako (Glostrup, Denmark).

\section{Tissue culture and tissue samples}

Tissue culture materials were purchased from Sarstedt (Nümbrecht, Germany). Culture media were purchased from Invitrogen Life Technologies (Carlsbad, CA, USA). Experiments were carried out on murine pancreatic islets or dispersed $\beta$-cells from Wistar rat and C57BL/6 mice. Animals were anesthetized with Nembutal before decapitation. All experimental procedures were conducted in agreement with the protocol approved by the Ethical and Animal Welfare Committee of the Université Libre de Bruxelles (protocol number $375 N$ ). Human cadaveric islet total RNA was kindly provided by Dr Ramon Gomis from the Barcelona Hospital Clinic. Approval of the experimental use of the islets was granted by the Barcelona Hospital ethics committee, and informed consent was given by the donors' families.

\section{Methods}

\section{Preparation of rat and mouse pancreatic islets}

Pancreatic islets were isolated by collagenase technique [42]. Bile duct was clamped at its entrance in the duodenum, and a cannula was inserted to inject 15 -ml Hank's-glucose solution 
containing $5.8 \mathrm{mg}$ collagenase $\mathrm{P}$ by rat or 2-ml Hank's-glucose solution containing $4 \mathrm{mg}$ collagenase $\mathrm{P}$ by mouse, in order to distend the pancreas and digest the exocrine gland. Hank's-glucose solution contained the following (in $\mathrm{mM}$ ): $137 \mathrm{NaCl}, 5.4 \mathrm{KCl}, 1.2 \mathrm{CaCl}_{2}, 0.8 \mathrm{MgSO}_{4}, 0.3 \mathrm{Na}_{2} \mathrm{HPO}_{4}$, $0.4 \mathrm{KH}_{2} \mathrm{PO}_{4}, 4.2 \mathrm{NaHCO}_{3}$, and 11.1 glucose, $\mathrm{pH}$ 7.4. The inflated pancreas was extracted and incubated for $15 \mathrm{~min}$ (rat) or $9 \mathrm{~min}$ (mouse) at $37{ }^{\circ} \mathrm{C}$ in a $50-\mathrm{ml}$ conical tube. Digestion was then stopped by addition of $20-\mathrm{ml}$ ice cold Hank's-glucose solution. The suspension was first gently agitated for $1 \mathrm{~min}$ and then vigorously for few seconds. The preparation was transferred in a crystallizing dish before three successive dilution-resuspension-sedimentation-aspiration cycles with $60-\mathrm{ml}$ ice cold Hank's-glucose solution in order to remove collagenase and floating exocrine acini. Islets were individually collected under a microscope using a pipette and laid at room temperature, on a Petri dish with 4-ml culture medium containing $5 \mathrm{mM}$ glucose (RPMI \#21875-034 GIBCO containing $11.1 \mathrm{mM}$ glucose diluted with RPMI \#11879-020 GIBCO glucose-free, $10 \%$ heat inactivated fetal bovine serum \#10500-064 GIBCO, $50 \mathrm{IU} / \mathrm{ml}$ penicillin, $50 \mu \mathrm{g} / \mathrm{ml}$ streptomycin \#15070-063 GIBCO). This last step was repeated three to four times to wash islets. Four hundred to six hundred pancreatic islets were obtained from one single rat pancreas, while 20 to 100 islets were isolated from one mouse. The Petri dish containing the islets was then placed at $37{ }^{\circ} \mathrm{C}$ in a humidified incubator gassed with $5 \% \mathrm{CO}_{2}$ in air. Each preparation was obtained by pooling islets from two animals. The islets were immediately used for experiments.

\section{Preparation of dispersed rat or mouse islet cells}

Freshly isolated pancreatic islets from two animals were suspended in a $1.5-\mathrm{ml}$ tube. The culture medium was discarded and replaced by a $0.5-\mathrm{ml}$ isotonic $0.05 \%$ trypsin-EDTA solution (\#25300-054 GIBCO) before incubation at $37{ }^{\circ} \mathrm{C}$, in a humidified incubator gassed with $5 \% \mathrm{CO}_{2}$ in air for $9 \mathrm{~min}$. After incubation, the trypsinEDTA solution was replaced by $0.62-\mathrm{ml}$ culture medium containing $11.1 \mathrm{mM}$ glucose and cells were separated by tenfold gentle suction-pushing with a pipette. Thirty-five to $50 \mu \mathrm{l}$ of cell suspension was laid onto 1.0 -cm-diameter glass poly-L-lysine (PLL)-precoated coverslips (Merck, Darmstadt, Germany). The coating procedure consisted to bath the coverslips for $5 \mathrm{~min}$ in a 0.1 or $0.3 \mathrm{mg} / \mathrm{ml} \mathrm{PLL}$ solution in sterile Milli-Q water before successively rinsing again in sterile Milli-Q water and drying overnight at room temperature in six-well plates. Afterward, cells were placed at $37{ }^{\circ} \mathrm{C}$ in a humidified incubator gassed with $5 \% \mathrm{CO}_{2}$ in air for $30 \mathrm{~min}$ to promote adherence before gentle addition of 4-ml culture medium containing $5 \mathrm{mM}$ glucose. Finally, cells were stored overnight in the incubator before experiments.

\section{Insulin release}

Groups of eight rat pancreatic islets were placed in 1.5- or 2$\mathrm{ml}$ assay tubes. Islets were first preincubated for $30 \mathrm{~min}$ in 1$\mathrm{ml}$ Hepes-buffered $\mathrm{NaCl}$ solution without bicarbonate or in Hepes and bicarbonate-buffered $\mathrm{NaCl}$ solution both supplemented with 1 or $5 \mathrm{mg} / \mathrm{ml}$ bovine serum albumin (BSA) and $2.8 \mathrm{mM}$ glucose in presence (or not) of T-AO1, TA, DMSO, rabbit blocking Ano1 antibodies (ab72984, Abcam), or rabbit whole serum and next incubated for $90 \mathrm{~min}$ in the same medium at various glucose concentrations: $2.8,8.3$, and $16.7 \mathrm{mM}$. Hepes-buffered $\mathrm{NaCl}$ solution without bicarbonate contained the following (in $\mathrm{mM}$ ): $140 \mathrm{NaCl}, 10 \mathrm{Hepes}, 4 \mathrm{KCl}$, $1 \mathrm{MgCl}_{2}$, and $1 \mathrm{CaCl}_{2}, \mathrm{pH} 7.3$, with $\mathrm{NaOH}$. Hepes and bicarbonate-buffered $\mathrm{NaCl}$ solution contained the following (in $\mathrm{mM}$ ): $111 \mathrm{NaCl}, 10$ Hepes, $5 \mathrm{KCl}, 1 \mathrm{MgCl}_{2}, 1 \mathrm{CaCl}_{2}$, and $24 \mathrm{NaHCO}_{3}, \mathrm{pH} 7.4$, with $\mathrm{NaOH}$. After 90 min, 0.2- or 0.5 -ml incubation medium was collected. Sampled incubation media were frozen for insulin content determination. Experiments were performed at $37^{\circ} \mathrm{C}$. In presence of bicarbonate media, preincubation and incubation were performed in a humidified incubator gassed with $5 \% \mathrm{CO}_{2}$ in air. Insulin content of each sample was measured by radio immmunoassay technique [40] or by ELISA (\#10-1250-10 Insulin, rat ELISA, Mercodia, Uppsala, Sweden).

\section{Patch-clamp experiments}

Mouse islets were immobilized at the end of a negatively pressured large borosilicate glass pipette, in the patch-clamp chamber using a micromanipulator (Prior, England). Whole islets were blind-patched between day 0 and day +2 . These experiments were carried out on mouse islets, as the sealing could not be maintained for prolonged periods with $\beta$-cell from whole rat islet. Dispersed rat or mouse islet cells cultured onto poly-L-lysine-precoated glass coverslips were used between day +1 and day +3 . $\beta$-Cells (representing $80-90 \%$ of the cells) were visually identified by their large size and their granular appearance [8]. Islets or coverslips were placed in the patch-clamp chamber and continuously perfused $(1 \mathrm{ml} / \mathrm{min})$. The temperature in the chamber was maintained at $34^{\circ} \mathrm{C}$ with a homemade heater (gift from Prof D. Gall, Department of Biophysics, ULB, Belgium). The patch pipettes were double-step pulled from borosilicate glass capillaries (Hilgenberg GmbH, Malsfeld, Germany) using a vertical puller (PC-10, Narishige International, London, UK). Liquid junction potentials were balanced after formation of a gigaseal contact. Voltages and currents were monitored with a PC501A amplifier (Warner Instruments, Hamden, CT, USA) or an Axopatch 200A (Axon instruments, Inc., Foster City, CA, USA). Zero-current whole-cell voltages and currents were continuously recorded using WinEDR or WinWCP software (John Dempster, Strathclyde Institute of Pharmacy and 
Biomedical Sciences, UK). $\beta$-Cells were functionally identified by the presence of action potential (AP) bursts induced by stimulating glucose concentration.

\section{Voltage measurements}

Nystatin-perforated whole-cell configuration patch-clamp experiments were conducted as previously described [70]. Bath solution was a Hepes-buffered $\mathrm{NaCl}$ solution without bicarbonate (see "Insulin release" section) supplemented with 2.8 or $16.7 \mathrm{mM}$ D-glucose or low chloride $(20 \mathrm{mM})$ by replacement of $140 \mathrm{mM} \mathrm{NaCl}$ in Hepes-buffered $\mathrm{NaCl}$ solution without bicarbonate by $12 \mathrm{mM} \mathrm{NaCl}$ and $128 \mathrm{mM} \mathrm{Na}$-gluconate, osmolarity 311 or $325 \mathrm{mOsmol} / \mathrm{l}$. Pipette solution contained the following (in $\mathrm{mM}$ ): $10 \mathrm{NaCl}, 20 \mathrm{KCl}, 75 \mathrm{~K}_{2} \mathrm{SO}_{4}$, and 10 Hepes, $\mathrm{pH} 7.2$, with $\mathrm{KOH}$, supplemented with 50 to $300 \mu \mathrm{g} / \mathrm{ml}$ nystatin, osmolarity $299 \mathrm{mOsmol} / \mathrm{l}$. Stock solution of nystatin (10 to $30 \mathrm{mg} / \mathrm{ml}$ in DMSO) was daily prepared. Filled pipettes had resistances of 6-10 $\mathrm{M} \Omega$. Whole-cell configuration induced by nystatin permeabilization was achieved within 10 to $15 \mathrm{~min}$. Leak resistance after sealing was usually at least $3 \mathrm{G} \Omega$. Access resistance (Rs) was $<35 \mathrm{M} \Omega$. Cells were stored in incubator and used within 60-min incubation. The effects of T-AO1 or TA on islets were evaluated during active phase after 5-min exposure for at least 3 min or more (30$40 \mathrm{~min})$. APs were counted for 3 min during active phase, $1 \mathrm{~min}$ at the beginning, 1 in the center, and 1 at the end. On dispersed cells, the effect of $16.7 \mathrm{mM}$ glucose was evaluated during the spiking activity for at least $30 \mathrm{~s}$ or more (1-2 min). The effects of T-AO1 and TA on the potential and APs were evaluated after 1- or 2-min exposure for at least $1 \mathrm{~min}$ or more (3-6 min). In low-chloride solution in presence of $200 \mu \mathrm{M}$ bumetanide, the initial effect of glucose (Ini) was evaluated during 20 to $60 \mathrm{~s}$ at the beginning of the spiking activity before the rundown of AP peak. Its effect in presence of bumetanide was also evaluated after 5-min glucose stimulation for a period of at least $5 \mathrm{~min}(\mathrm{G}+5 \mathrm{~min})$. The effect of $5 \mathrm{mM}$ acetazolamide on glucose and bumetanide was further evaluated after 5 -min acetazolamide incubation and for a period of at least $5 \mathrm{~min}($ Acet $+5 \mathrm{~min})$

\section{Chloride current measurements}

Chloride currents from rat dispersed $\beta$-cells were measured on inside-out single excised patches and whole cell. Filled pipette resistance was $5 \mathrm{M} \Omega$ (Fig. 5) except for single-channel currents, $20 \mathrm{M} \Omega$ (Fig. 6). Sealing was first performed in Hepesbuffered $\mathrm{NaCl}$ solution without bicarbonate containing $2.8 \mathrm{mM}$ glucose (see "Insulin release" section). On insideout single excised patches (macropatches, filled pipette resistance $5 \mathrm{M} \Omega$, Fig. 5), the bathing solution was replaced after sealing by $150 \mathrm{mM} \mathrm{N}$-methyl D-glucamine chloride (NMDG$\mathrm{Cl}), \mathrm{pH}$ 7.3, solution containing $\mathrm{CaCl}_{2}$ at the indicated concentration ( 0 to $2 \mu \mathrm{M}$ ), which flowed during $90 \mathrm{~s}$ before excision. After excision, leak resistance was 7-25 G $\Omega$. Measurements were performed after 2-min exposure of the cytoplasmic side of the patch to bath solution. Pipette solution contained also $150 \mathrm{mM}$ NMDG-Cl, $\mathrm{pH} 7.3$, in presence or absence of $10 \mu \mathrm{M}$ T-AO1, active blocking Ano1 antibodies ab72984 1:100 or boiled (heated at $99^{\circ} \mathrm{C}$ for $10 \mathrm{~min}$ ) blocking Ano1 antibodies ab72984 1:100. In the experiments with TAO1 or antibodies, sealing was performed $5 \mathrm{~min}$ before measurements so that a 5 -min preincubation occurred. Current traces recorded (sampling rate, $25 \mathrm{kHz} ; 2-\mathrm{kHz}$ filter setting) were induced by $1500-\mathrm{ms}$ voltage steps from -100 to + $100 \mathrm{mV}$, spaced $20 \mathrm{mV}$ (holding potential, $-70 \mathrm{mV}, 200 \mathrm{~ms}$ before and after each step). Steady-state current-voltage relationship was constructed from the average $\mathrm{Cl}^{-}$currents measured between ms 1400 and 1500 of voltage stimulation. In voltage step experiments, the stability of $\mathrm{Cl}^{-}$currents at the holding potential $(-70 \mathrm{mV})$ before the 11 voltage steps was indicative of the stability of $\left[\mathrm{Ca}^{2+}\right]_{\mathrm{i}}$ and of the absence of apparition of sudden leakage currents. Single-channel $\mathrm{Cl}^{-}$currents were also measured on inside-out excised patches (filled pipette resistance $20 \mathrm{M} \Omega$, Fig. 6). After sealing, the bathing medium was replaced just before excision, by a $150 \mathrm{mM}$ NMDG-Cl, pH 7.3, calcium-free medium. Stimulation of $\mathrm{CaCC}$ was performed with the same medium containing $1 \mu \mathrm{M} \mathrm{CaCl}_{2}$. Pipette solution was $150 \mathrm{mM}$ NMDG-Cl, $\mathrm{pH}$ 7.3 , supplemented with $10 \mu \mathrm{M}$ glibenclamide and $10 \mu \mathrm{M}$ nifedipine and contained (or not) $100 \mu \mathrm{M}$ T-AO1 or TA. Currents were corrected for leakage. Leak resistance after sealing was usually 7 to $15 \mathrm{G} \Omega$. Single-channel records were analyzed using pCLAMP software where all event lists of singlechannel records were generated by Fetchan program (Molecular Devices, Sunnyvale, CA). NPo, the product of the number of channels in a patch $(N)$ by the open probability $(\mathrm{Po})$, which reflects the channel activity within a patch, was calculated using the equation

$$
N P o=\sum_{i=1}^{N} i^{*} t_{i} / T
$$

where $T$ is the total recording time, $i$ is the number of open channels, $t_{i}$ is the recording time during which $i$ channels were open, and $N$ is the apparent number of channels within the determined patch (as the highest observable level). Therefore, $N P o$ can be calculated without making any assumption about the total number of channels in a patch or the open probability of single channels. All NPo values were calculated for $120 \mathrm{~s}$ of recording after 15 -s stimulation with $1 \mu \mathrm{M} \mathrm{Ca}^{2+}$. To meet the electrophysiological convention, inward $\mathrm{Cl}^{-}$currents from inside-out patches (pipette to cell) were represented as upward transitions. In whole-cell experiments, pipette solution was $150 \mathrm{mM}$ NMDG-Cl, $\mathrm{pH} 7.2$, containing 0 or $1 \mu \mathrm{M} \mathrm{CaCl}_{2}$, in presence or absence of blocking Ano1 antibodies ab72984 
1:100 or boiled blocking Ano1 antibodies ab72984 1:100 (cytosolic side of the cell). After sealing, the bathing solution was replaced by $150 \mathrm{mM}$ NMDG-Cl, $\mathrm{pH}$ 7.3. The membrane was ruptured by suction to form a whole cell. Access resistance was about $10 \mathrm{M} \Omega$. Series resistance was $50 \%$ compensated. Leak resistance was 7-25 G . Measurements were performed 6 min after whole-cell formation or from 6 to 12 min with blocking Ano1 antibodies. In the experiments with T-AO1, the bathing solution was replaced 2 min before measurements by $150 \mathrm{mM}$ NMDG-Cl, pH 7.3, containing $10 \mu \mathrm{M}$ T-AO1 which was thus preincubated for 2 min externally. Current traces recorded (sampling rate, $10 \mathrm{kHz} ; 2-\mathrm{kHz}$ filter setting) were induced by $400-\mathrm{ms}$ voltage steps from -100 to $+100 \mathrm{mV}$, spaced $20 \mathrm{mV}$ (holding potential, $-70 \mathrm{mV}, 100 \mathrm{~ms}$ before and after each step). Current-voltage relationship was constructed from the average $\mathrm{Cl}^{-}$currents measured between ms 380 and 400 of voltage stimulation. In monovalent anion permeability experiments (also whole-cell experiments), an agar- $\mathrm{KCl} 3 \mathrm{M}$ salt bridge provided the junction between the $\mathrm{Ag} / \mathrm{AgCl}$ reference electrode and the bath. Pipette solution was $150 \mathrm{mM}$ NMDG-Cl, pH 7.2, containing $1 \mu \mathrm{M} \mathrm{CaCl}_{2}$. The bathing solution (150 mM NMDG-Cl) was replaced by $150 \mathrm{mM}$ NMDG-NO ${ }_{3}$ or NMDG-Br, pH 7.3, which flowed during $1.5 \mathrm{~min}$ before a first measurement performed $6 \mathrm{~min}$ after whole-cell formation. The bathing solution was then exchanged with $150 \mathrm{mM}$ NMDG-Cl for $1.5 \mathrm{~min}$ before a second measurement. Current traces recorded (sampling rate, $25 \mathrm{kHz}$; $2-\mathrm{kHz}$ filter setting) were induced by a slow voltage ramp: from holding potential $(-70 \mathrm{mV}, 200 \mathrm{~ms})$, a step to $-100 \mathrm{mV}, 400 \mathrm{~ms}$ was applied followed by a 10 -s linear voltage ramp from -100 to $+100 \mathrm{mV}$ with thereafter a step to holding potential, $-70 \mathrm{mV}, 200 \mathrm{~ms}$. Parts of ramps from -40 to $+40 \mathrm{mV}$ are represented in Fig. $5 \mathrm{j}, 1$.

\section{Barium current measurements}

In whole-cell experiments, cells were first immersed in Hepesbuffered $\mathrm{NaCl}$ medium containing $2.8 \mathrm{mM}$ glucose (see "Insulin release" section). After establishing the whole-cell configuration, the medium was then replaced by a barium solution containing (in mM) $75 \mathrm{BaCl}_{2}, 10$ Hepes, 35 NMDG-gluconate, $\mathrm{pH} 7.3$, with NMDG, osmolarity $310 \mathrm{mOsm} / 1$ and supplemented (or not) with $100 \mu \mathrm{M}$ Anol inhibitors (T-AO1 or TA) or $10 \mu \mathrm{M}$ nifedipine. Pipette solution contained (in mM) 103 NMDG-Cl, 10 Hepes, 3 MgATP, 43 NMDG-gluconate, $10^{-4}$ CaGluconate $_{2}$, pH 7.15 with NMDG, osmolarity $310 \mathrm{mOsm} / \mathrm{l}$. Chloride equilibrium potential was $-10 \mathrm{mV}$. Holding potential was $-70 \mathrm{mV}$. Filled pipette resistance was $5 \mathrm{M} \Omega$. Leak resistance was at least $3 \mathrm{G} \Omega$ (usually 4 to $7 \mathrm{G} \Omega$ ) after establishment of the sealing. Access resistance (Rs) was between 10 and $20 \mathrm{M} \Omega$. The currents have been corrected for leakage and capacity currents. Series resistance was compensated by $50 \%$. $\mathrm{Ba}^{2+}$ currents were observed during 200-ms depolarizations to $-10 \mathrm{mV}$ from a holding potential of $-70 \mathrm{mV}$ in the absence or presence of T-AO1 $(100 \mu \mathrm{M})$, TA $(100 \mu \mathrm{M})$, or nifedipine $(10 \mu \mathrm{M})$ in the bathing medium and normalized (or not) to the capacitance of each cell. To establish the peak inward current $(I)$-voltage $(V)$ relationship, 25-ms depolarizations from -50 to $+30 \mathrm{mV}$ by $10-$ $\mathrm{mV}$ voltage steps were applied from a holding potential of $-70 \mathrm{mV}$. Only the first set of measurements was considered for each cell to avoid a rundown of the currents.

\section{Reverse transcriptase for Ano1}

Total RNA from rat and human tissues (pancreas, kidney) was extracted using the AURUM ${ }^{\mathrm{TM}}$ total RNA fatty acid and tissue kit (Bio-Rad, Hercules, CA, USA), and then, complementary DNA (cDNA) was prepared using the High-Capacity cDNA Reverse Transcription kit (Applied Biosystems, Waltham, MA, USA). RT-PCR reactions were carried out in $20-\mu$ f final volume containing the following: $1 \mu \mathrm{l}$ of cDNA added to $4 \mu \mathrm{l}$ of Go Taq Green $5 \times$ Buffer, $0.2 \mathrm{mM}$ dNTP, $0.5 \mu \mathrm{M}$ of each primer, and $0.5 \mathrm{U}$ Go Taq ${ }^{\mathrm{TM}}$ polymerase (Promega, Madison, WI) using MyCycler ${ }^{\text {TM }}$ Thermal Cycler (Bio-Rad Laboratories, Hercules, USA). Primers used (GenBank accession no. NM_001107564) for rat Ano1 were as follows: forward 5'GCAGGCCTGGAGCTGGAACG-3'and reverse 5' GCTCAGCCACCTTGGGCTGG-3', and those (GenBank no. NM_018043) for human Ano1: forward 5'CACAGGCGGCCACGATGAGG-3' and reverse 5'GGGGTGGTCCTGCTTGACGC-3'. Thermocycler conditions were:denaturation at $95^{\circ} \mathrm{C}$ for $90 \mathrm{~s}$ followed by 35 cycles $\left(95^{\circ} \mathrm{C}\right.$ for $30 \mathrm{~s}, 60^{\circ} \mathrm{C}$ for $30 \mathrm{~s}, 72^{\circ} \mathrm{C}$ for $1 \mathrm{~min}$ ) and finished by a final elongation at $72^{\circ} \mathrm{C}$ of $5 \mathrm{~min}$. Amplicons were separated on a $1.2 \%$ agarose gel in TAE buffer (40 mM Tris base, $20 \mathrm{mM}$ acetic acid, $1 \mathrm{mM}$ EDTA, pH 7.4, supplemented with $0.5 \mu \mathrm{g} / \mathrm{ml}$ ethidium bromide). Gels were visualized by UV translumination, using a GelDoc apparatus (Fusion FX5 Vilber Lourmat). A sequence analysis was performed on purified PCR products: $5 \mu$ l of PCR products was treated with ExoSAP-IT enzyme (Affymetrix Santa Clara, CA, USA) in order to remove excess dNTPs and residual primers. The reaction was carried out at $37^{\circ} \mathrm{C}$ for $15 \mathrm{~min}$ and stopped by heating at $80{ }^{\circ} \mathrm{C}$ for $15 \mathrm{~min}$. Two microliters of the mix PCR/ExoSAPIT was mixed with $2 \mu \mathrm{l}$ Ano 1 primers $3.5 \mathrm{pmol} / \mu \mathrm{l}$, and volume was finally completed to $7 \mu$ with water. Sequencing was subcontracted to external services (Beckman coulter genomics, Danvers, MA, USA), and the sequences were compared using nucleotide BLAST search program (BLAST2SEQ) of NCBI database. (http://www.ncbi.nlm.nih.gov).

\section{Immunodetection analysis of Ano1 in rat islets}

Immunodetection of Anol was performed by Western blotting. Islets were isolated, as previously described, from two 
rats and lysed into $60 \mu \mathrm{l}$ ice cold RIPA lysis buffer $(50 \mathrm{mM}$ Tris base, $\mathrm{pH} 7.4,150 \mathrm{mM} \mathrm{NaCl}, 1$ \% NP-40, $0.25 \%$ sodium desoxycholate, and supplemented with Roche protease inhibitor tablet). Protein concentration, measured by Bradford, was $4 \mu \mathrm{g} / \mu \mathrm{l}$. After centrifugation $(16,000$ rcf, $15 \mathrm{~min}$ ), samples were supplemented with Laemmli buffer/1 \% dithiothreitol (Laemmli 4×: $250 \mathrm{mM}$ Tris$\mathrm{HCl}, \mathrm{pH} 6.8,40 \%$ glycerol, $5 \%$ SDS, bromophenol blue; sample: Laemmli buffer $4 \times, 3 v: 1 \quad v$ ) and denatured by heating at $70{ }^{\circ} \mathrm{C}$ for $30 \mathrm{~min}$. Proteins were separated on a $5 \%$ acrylamide gel and transferred to a PVDF membrane. Procedure was as previously described [45]. After blocking, the membrane was successively incubated overnight at $4{ }^{\circ} \mathrm{C}$ with a rabbit polyclonal anti-ANO1 (ab84115, Abcam) 1:1000, rinsed, and incubated at room temperature for $2 \mathrm{~h}$ with HRPconjugated anti-rabbit. Detection was performed by exposure to enhanced chemiluminescence (Amersham). Human thyroid extract was used as positive control. Molecular weight of rat Anol was estimated at $119 \mathrm{kDa}$, from Rattus norvegicus peptide sequence (NP_001101034.1, NCBI).

\section{Immunofluorescence detection of Ano1 in rat pancreas sections}

Pancreas was quickly dissected and further fixed by overnight immersion in $4 \%(w / v)$ paraformaldehyde in $0.1 \mathrm{M}$ phosphate buffer, $\mathrm{pH}$ 7.4. The tissue was then transferred to successive graded sucrose solutions $(10,20$, and $30 \%$, overnight each) and finally embedded in Tissue-Tek $\mathrm{OCT}^{\mathrm{TM}}$ compound (Sakura Finetek Europe, Leiden, the Netherlands), snap-frozen in cold 2-methylbutane, and stored at $-80{ }^{\circ} \mathrm{C}$. Cryosections $(10 \mu \mathrm{m})$ were cut on a cryostat (Leitz, Iena, Germany), mounted on glass slides (International Medical Products, Brussels, Belgium), coated with $0.1 \%$ poly-L-lysine, and stored at $-20{ }^{\circ} \mathrm{C}$ until use. Before the immunostaining immunofluorescence procedure, the slides were submitted to an epitope unmasking procedure: the slides were immerged in a $0.01 \mathrm{M}$ citrate buffer, $\mathrm{pH}$ 6, and boiled in a microwave oven for $10 \mathrm{~min}$ $(2450 \mathrm{MHz}, 850 \mathrm{~W})$. The slides remained in the plastic jars for $15 \mathrm{~min}$ until cooling to room temperature, were then washed with a Tris-buffered saline solution (TBS, composition in $\mathrm{mM}$ : 50 Tris-HCl, $110 \mathrm{NaCl}, \mathrm{pH} 7.5$ ) and dropped for $30 \mathrm{~min}$ in methanol containing $0.3 \%$ hydrogen peroxide in order to block endogenous peroxidase activity. Slides were quickly washed in water, preincubated for $60 \mathrm{~min}$ in TBS supplemented with normal rabbit serum (NRS) 1:10, and incubated overnight at room temperature with either goat polyclonal anti-Ano1 sc-69343 (SantaCruz) 1:50 or for specificity control in a mix of antiAno1 sc-69343:Ano1 peptide ab97423 (Abcam) in ratio of $1: 8$ preincubated for $2 \mathrm{~h}$ in TBS containing NRS 1:100. The slides were washed in TBS and incubated for 30 min with a secondary rabbit anti-goat biotinylated antibody BA-5000 (Vector Laboratories) 1:300, rinsed in TBS, and incubated for $1 \mathrm{~h}$ with a streptavidin-peroxidase complex. The slides were washed again in TBS and incubated for 10 min with Tyramide Alexa Fluor 488 1:100 in the amplification buffer provided in the kit (T-20932, Thermo Fisher Scientific, Waltham, MA, USA). Finally, after rinsing twice in TBS, the cryostat slides were washed in water and mounted using Glycergel (Dako, Glostrup, Denmark) supplemented with $2.0 \%$ of the antifading compound 1,4diazobicyclo[2.2.2] octane (DABCO, Sigma, St Louis, MO, USA). Sections were examined with a Zeiss Axioplan microscope, and images were acquired using an AxioCam HRc camera. After the images were captured, a counterstaining of the same slides with hematoxylin and eosin confirmed the localization of the immunofluorescence signal at the level of the pancreatic islets.

\section{Statistics}

Results are presented as mean values ( \pm SEM) with the number of individual experiments $(n)$ except for Fig. $6 \mathrm{c}$ where all the points are showed. The normality of population distributions was assessed by Shapiro-Wilk tests. Datasets with normal distributions were compared using parametric tests. Datasets containing at least a non-normal distribution were compared using nonparametric tests. Statistic tests were performed using SPSS 22 software (IBM, Armonk, NY).

\section{Results}

\section{Expression of Ano1 in rat pancreatic islets}

By RT-PCR, the transcript of Ano1 was found in total pancreas and in purified islet preparation in both rat and human species. As kidney is well known to express Ano1 [23], messenger RNA (mRNA) extracted from kidney was used as positive control (Fig. 1a). The comparison of sequences of PCR products obtained by amplification of rat total pancreas, isolated islets, and kidney cDNAs vs. reference sequences was performed using BLAST2SEQ program (accession number: NM_001107564.1) and confirmed $100 \%$ identity. The expression of Ano1 protein in whole rat islets was assessed by western blotting ( 80 and $30 \mu \mathrm{g}$ prot/lane) using a human thyroid lysate as positive control. This clearly established that Ano1 is expressed in rat islet cells, as observed in human and mice $\beta$-cells [27]. Ano1 cellular distribution was further studied in the pancreas by immunofluorescence. A strong Ano1 staining was observed at the level of Langerhans' islet and in acinar cells at the apical side of 

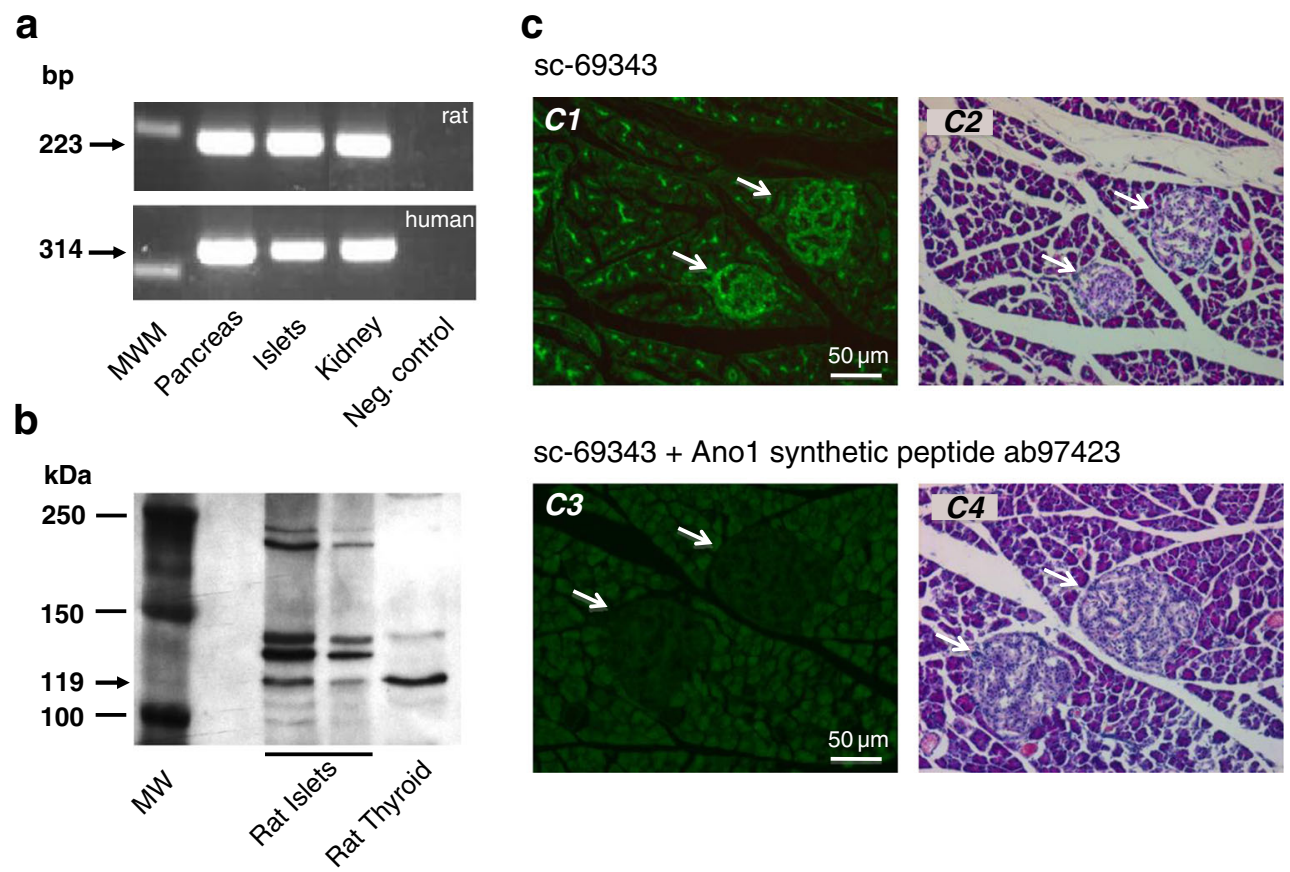

sc-69343 + Ano1 synthetic peptide ab97423
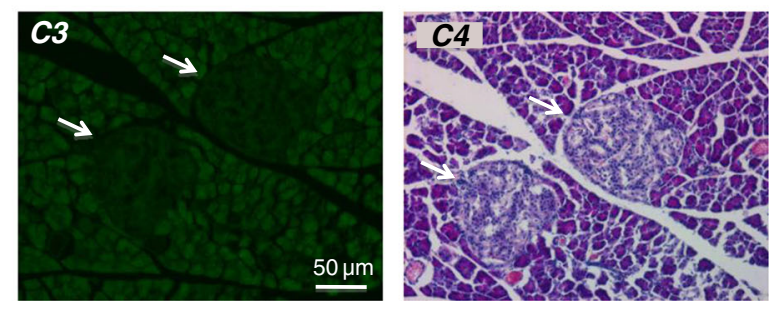

Fig. 1 Detection of Ano1 in pancreas and pancreatic islets. a RT-PCR of cDNA prepared from mRNA extracted from rat and human tissues. Transcripts of the expected size for Ano1 are observed (rat: $223 \mathrm{bp}$; human $314 \mathrm{bp}$ ). The 300-bp band is shown in the molecular weight marker column (MWM). Positive control: kidney. Negative control (Neg. control): no DNA. The sequencing of PCR products confirmed $100 \%$ identity with the reference sequence for rat Anol cDNA complementary of rat Anol mRNA. b Western blot of Ano1 in rat islets, from left to right: molecular weight column (MW) showing the $100-, 150-$, and $250-\mathrm{kDa}$ bands, $80 \mu \mathrm{g}$ rat islet lysate, $30 \mu \mathrm{g}$ rat islet lysate, and $30 \mu \mathrm{g}$ human thyroid lysate (positive control). Anol is detected at $119 \mathrm{kDa}$. $\mathbf{c}$ Immunofluorescence staining of pancreas section. c1 Immunohistochemical labeling (green-fluorescent Tyramide Alexa 488) of Ano1 in a section photomicrograph of rat pancreas. Most of the islet cells and acinar cells (at the level of apical pole) are labeled. $c 2$ Counterstaining labeling by hematoxylin-eosin performed on the slice used for $c 1$. $c 3$ Specificity control: immunohistochemical labeling of Ano1 in a section photomicrograph of rat pancreas. The primary goat Ano1 antibodies (sc-69343) were coincubated in the presence of Ano1 synthetic peptide (ab97423) in a ratio 1:8. The labeling disappears. $c 4$ Counterstaining labeling by hematoxylin-eosin performed on the slice used for c3. Arrows show islets. Scale bar is $50 \mu \mathrm{m}$ the acini (Fig. 1c). Almost all the cells of the islet were labeled (Fig. 1 (c1)) as confirmed by the hematoxylin-eosin counterstaining (Fig. 1 (c2)) which was performed on the same slice. Coincubation of the primary goat Anol antibodies with Ano1 synthetic peptide (which competes with tissue Ano1) in a ratio 1:8 completely prevented the labeling (Fig. 1 (c3)).

\section{Effect of Ano1 on GSIS in rat pancreatic islets}

In Hepes-buffered $\mathrm{NaCl}$ solution without bicarbonate (Fig. 2a), 8.3 and $16.7 \mathrm{mM}$ GSIS, respectively, represented $263.2 \pm 33.9\left(n=58, P=2.79 \times 10^{-12}\right)$ and $404.2 \pm 48.5 \%(n=$ $\left.59, P<10^{-13}\right)$ of the basal secretion $(n=58)$. When incubated with $8.3 \mathrm{mM}$ glucose, T-AO1 and TA $100 \mu \mathrm{M}$ completely prevented the insulin output increase (T-AO1: $n=30, P=$ $3.40 \times 10^{-13}$ vs. $8.3 \mathrm{mM}$ glucose, $P=0.878$ vs. $2.8 \mathrm{mM}$ glucose and TA: $n=29, P=1.30 \times 10^{-7}$ vs. $8.3 \mathrm{mM}$ glucose, $P>0.999$ vs. $2.8 \mathrm{mM}$ glucose). In presence of $16.7 \mathrm{mM}$ glucose, T-AO1 also abolished the relative increment in insulin output ( $n=30, P<10^{-13}$ vs. $16.7 \mathrm{mM}$ glucose, $P>0.999$ vs. $2.8 \mathrm{mM}$ glucose $)$, while TA reduced it to $32.6 \pm 10.6 \%(n=29$,
$P=6.39 \times 10^{-13}$ vs. $16.7 \mathrm{mM}$ glucose, $P=0.00292$ vs. $2.8 \mathrm{mM}$ glucose). GSIS $(16,7 \mathrm{mM})$ in the absence of bicarbonate (Fig. 2a) represented $39.3 \pm 4.3 \%$ of the insulin release measured in 24-mM bicarbonate medium (Fig. $2 \mathrm{~b}, P=1.16 \times 10^{-19}$ by independent Student's $t$ test), in agreement with the observation reported by Henquin and Lambert [29]. In bicarbonate medium, $16.7 \mathrm{mM}$ GSIS represented $905.7 \pm 218.5 \%$ of basal secretion (Fig. $2 \mathrm{~b}, n=20, P<0.001$ vs. $2.8 \mathrm{mM}$ glucose). TAO1 dose-dependently decreased $16.7 \mathrm{mM} \mathrm{GSIS} \mathrm{(Fig.} \mathrm{2b,} n=$ 19-32). No significant inhibitory effect was observed for TAO1 concentrations up to $30 \mu \mathrm{M}(3 \mu \mathrm{M}, P>0.999 ; 10 \mu \mathrm{M}$, $P>0.999 ; 30 \mu \mathrm{M}, P=0.371$ vs. $16.7 \mathrm{mM}$ glucose) although the 16.7-mM GSIS increment in presence of $30 \mu \mathrm{M}$ T-AO1 represented only $58.1 \pm 13.5 \%$. T-AO1 $100 \mu \mathrm{M}$ prevented any increase in GSIS $(P<0.001$ vs. $16.7 \mathrm{mM}$ glucose, $P>0.999$ vs. $2.8 \mathrm{mM}$ glucose). The importance of Ano1 in GSIS was also confirmed by the abolition of 16.7-mM GSIS increment by the blocking Anol antibodies ab72984 [14] in bicarbonate medium (Fig. 2c). The relative increment at 1:100 dilution was $23.9 \pm 16.0 \%$ (Fig. 2 (c3), $n=9-12, P=0.036$ vs. $16.7 \mathrm{mM}$ glucose and $P=0.15$ vs. $2.8 \mathrm{mM}$ glucose). 


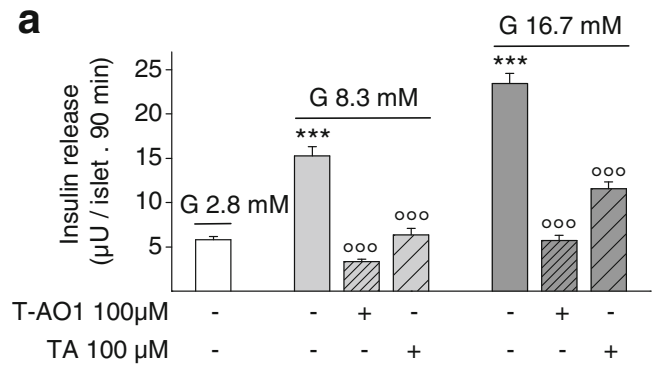

b

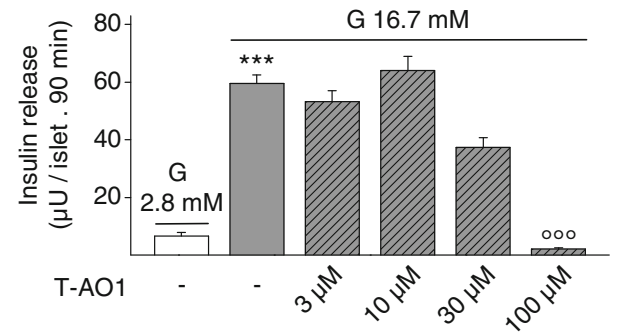

C

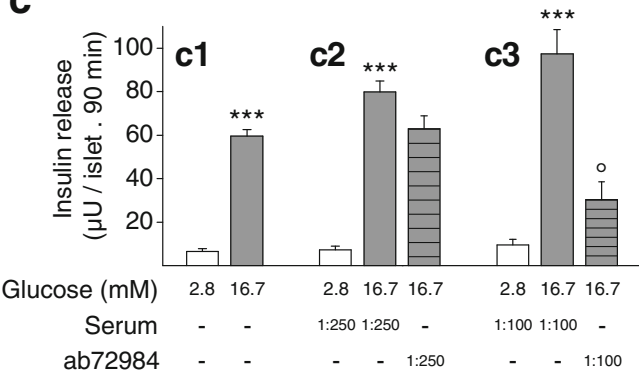

Fig. 2 Insulin release from rat pancreatic islets is drastically reduced in the presence of Anol inhibitors and blocking Anol antibodies. Islets were first preincubated in $2.8 \mathrm{mM}$ glucose, in the presence (or not) of T-AO1, TA, or blocking Ano1 antibodies (ab72984), and then incubated for $90 \mathrm{~min}$ in the same medium with different glucose concentrations $(2.8$, 8.3 , and $16.7 \mathrm{mM}$ ). The experiments were always performed on groups of eight islets isolated from preparations of two rats. a Effect of T-AO1 and TA $(100 \mu \mathrm{M})$ on glucose-stimulated insulin secretion (GSIS) from rat islets in Hepes-buffered $\mathrm{NaCl}$ solution without bicarbonate as used in the patch-clamp voltage measurements $(n=58-59$ from six preparations in conditions without inhibitors, $n=29-30$ from three preparations in conditions with inhibitors). Preincubation with T-AO1 or TA completely abolished the increment in insulin output on glucose 8.3$\mathrm{mM}$ stimulation. With $16.7 \mathrm{mM}$ glucose, no increase was observed in the presence of T-AO1, while the relative increase was weak with TA $(32.6 \pm 10.6 \%)$. b Dose-dependent effect of T-AO1 on $16.7 \mathrm{mM}$ GSIS from rat islets in Hepes and bicarbonate-buffered $\mathrm{NaCl}$ solution $(n=19$ 20 from three preparations except for $10 \mu \mathrm{M}$ T-AO1, $n=32$ ). T-AO1 $100 \mu \mathrm{M}$ prevented any increase in GSIS. $\mathbf{c}$ Effect of rabbit blocking Ano1 antibodies ab72984 (in whole serum) on $16.7 \mathrm{mM}$ GSIS from rat islets in Hepes and bicarbonate-buffered $\mathrm{NaCl}$ solution. $c 1$ No antibody/ no serum ( $n=20$ from two preparations). $c 2$ ab72984 or serum 1:250 and $c 3$ ab72984 or serum 1:100 ( $c 2$ and $c 3, n=9-12$ from three preparations). The relative increment in presence of 1:100 antibodies was reduced to $23.9 \pm 16.0 \%$ with a secretion value not significantly different from control ( $P=0.15$ vs. $2.8 \mathrm{mM}$ glucose). One-way ANOVA test on $\mathbf{a}, P=$ $1.41 \times 10^{-46}$; Kruskal-Wallis test on $\mathbf{b}, c 2, c 3, P<0.001$; Mann-Whitney test on $c 1, P<0.001 .{ }^{* * *} P<0.001$ vs. $2.8 \mathrm{mM}$ glucose condition; ${ }^{\circ} P<0.05,{ }^{\circ 0} P<0.001$ vs. $16.7 \mathrm{mM}$ glucose-stimulated condition (Sidak tests in a; Mann-Whitney-type tests with Dunn-Bonferroni correction in b, $c 2, c 3)$

\section{Effect of Ano1 inhibitors T-AO1 and TA on the membrane potential of $\beta$-cell from whole mouse islet}

Zero-current nystatin-perforated patch-clamp voltage recordings were performed on cells from intact islets stimulated with $16.7 \mathrm{mM}$ glucose. After a first prolonged depolarization, a cyclic pattern of membrane potential fluctuations was observed with alternating depolarized active phases (slow waves with bursts of spikes) and partially repolarized silent phases, as previously reported $[25,30]$. Figure 3 a shows such a representative membrane voltage recording in a cell stimulated with $16.7 \mathrm{mM}$ glucose.

The effects of T-AO1 and TA inhibitors $(100 \mu \mathrm{M})$ were evaluated after 5-min exposure. APs were counted for $3 \mathrm{~min}$ during the active phase ( $1 \mathrm{~min}$ at the beginning, 1 in the middle, and 1 at the end). Representative membrane voltage recordings in presence of T-AO1 or TA are presented in Fig. 3b, g. The greatest impact of inhibitors occurred on AP rate: TAO1 largely reduced glucose-stimulated AP rate, averaging $4.74 \pm 0.58 \mathrm{~s}^{-1}$ to $1.17 \pm 0.86$, i.e., by $78.7 \pm 14.1 \%$ (Fig. $3 \mathrm{c}, n=$ $\left.3, P=6.30 \times 10^{-3}\right)$. A reduction from $4.91 \pm 0.62$ to $3.32 \pm$ $0.50 \mathrm{~s}^{-1}$, thus by $33.5 \pm 5.1 \%$, occurred with TA (Fig. 3h, $n=7, P=2.44 \times 10^{-3}$ ). Ano1 inhibition with TA repolarized also the AP peak that averaged $-15.41 \pm 3.73$ to $-24.47 \pm$ $3.03 \mathrm{mV}$, thus by $9.06 \pm 1.13 \mathrm{mV}$ (Fig. 3i, $n=9, P=4.18 \times$ $10^{-5}$ ), but T-AO1 repolarization from $-18.71 \pm 1.58$ to $-22.65 \pm 2.68 \mathrm{mV}$, i.e., by $3.94 \pm 1.41 \mathrm{mV}$, was not significant (Fig. 3d, $n=3$ ). TA also provoked a significant reduction of $33.9 \pm 2.5 \%$ of AP amplitude $(39.09 \pm 4.40 \mathrm{mV}$ in its absence vs. $26.23 \pm 3.89 \mathrm{mV}$ in its presence, Fig. $3 \mathrm{i}, n=9, P=3.00 \times$ $10^{-6}$ ), while T-AO1 did not (Fig. 3e, $n=3$ ), Glucose stimulation depolarized the cell (resting potential $-74.02 \pm 0.93 \mathrm{mV}$, $n=12$ ), and during active phase, the plateau potential averaged $-53.42 \pm 1.34 \mathrm{mV}\left(n=12, P=5.19 \times 10^{-8}\right)$. The inhibitors did not repolarize the plateau potential: Fig. $3 \mathrm{f}$ (T-AO1) and Fig. 3k (TA). The fraction of plateau phase (FOPP, relative duration of the active phase) of $16.7 \mathrm{mM}$ glucose-stimulated $\beta$-cell with glucose approached a value of $60 \%[56,81]$. In presence of TA, the duration of both silent and active phases was about threefold extended with almost no effect on FOPP which barely decreased from $0.615 \pm 0.026$ to $0.589 \pm 0.059$ $(n=6, P=0,733$, paired $t$ test).

\section{Effect of Ano1 inhibition on the membrane potential from rat and mice dispersed $\beta$-cells}

Zero-current nystatin-perforated patch-clamp voltage recordings were performed on single dispersed $\beta$-cells stimulated with glucose. Only cells showing a resting potential of $-70 \pm$ $8 \mathrm{mV}$ were examined: $16.7 \mathrm{mM}$ glucose induced a pattern of electrical activity with numerous repetitive fast-spiking activity. The addition of T-AO1 or TA into the bathing medium is shown in Fig. 4a, d for rat cells and in Fig. 4g for mice cells. 

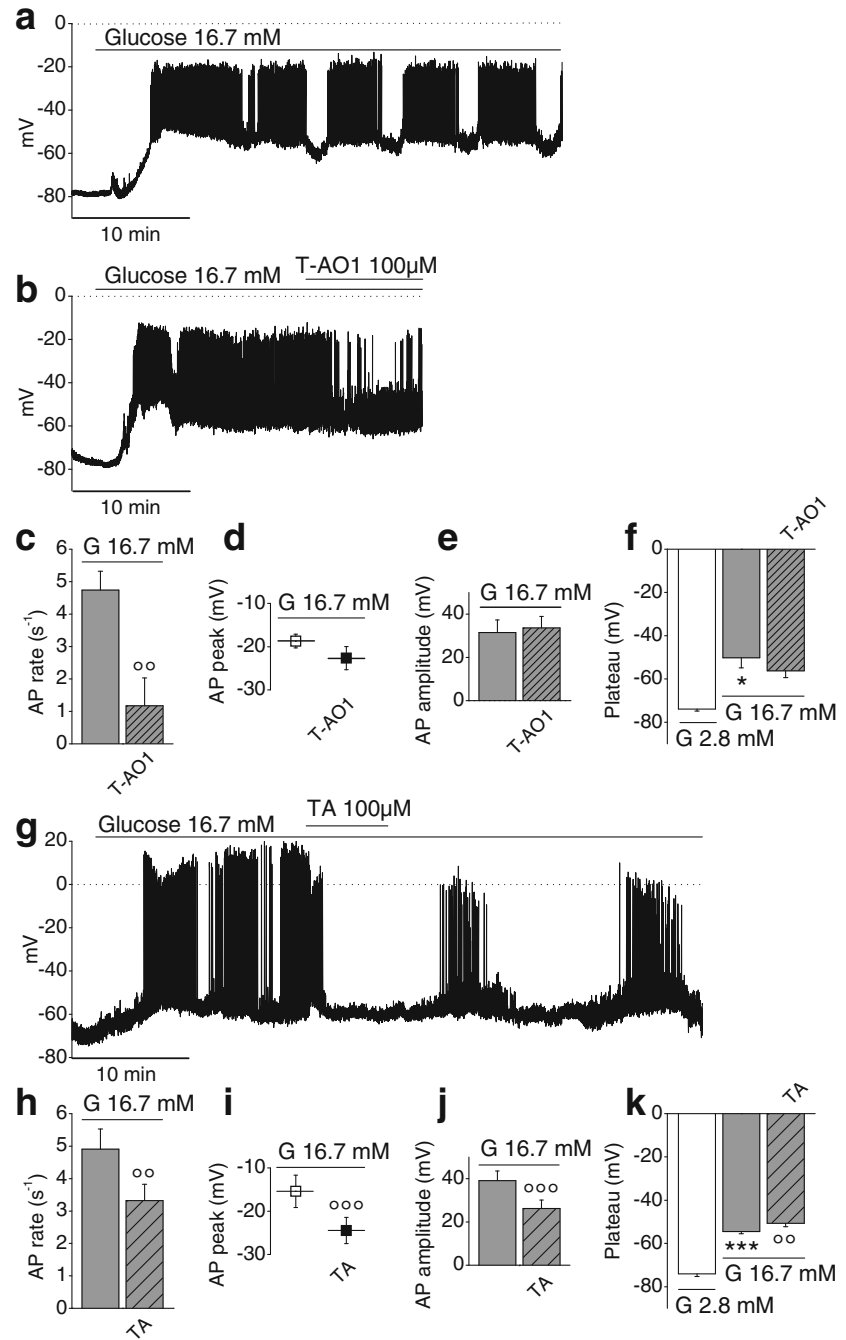

Fig. 3 Effect of Ano1 inhibitors on the membrane potential of $\beta$-cell from whole mice islet stimulated with $16.7 \mathrm{mM}$ glucose. a, b, g Representative zero-current nystatin-perforated patch-clamp voltage recordings. Sampling rate, $18 \mathrm{kHz} ; 2-\mathrm{kHz}$ filter setting. Dotted lines represent zero-voltage level. a Glucose-stimulated cell $(16.7 \mathrm{mM}$ glucose). b Glucose-stimulated cell $\pm 100 \mu \mathrm{M}$ T-AO1 in the bathing medium. c Effect of T-AO1 $(n=3)$ on action potential (AP) rate, in presence of glucose. d Effect of T-AO1 $(n=3)$ on AP peak, in presence of glucose. e Effect of T-AO1 $(n=3)$ on AP amplitude, in presence of glucose. $\mathbf{f}$ Effect of T-AO1 $(n=3)$ on the membrane plateau potential during active phase in presence of glucose. $\mathbf{g}$ Glucose-stimulated cell \pm $100 \mu \mathrm{M}$ TA in the bathing medium. $\mathbf{h}$ Effect of TA $(n=7)$ on action potential rate, in presence of glucose. i Effect of TA $(n=9)$ on AP peak, in presence of glucose. $\mathbf{j}$ Effect of TA $(n=9)$ on AP amplitude, in presence of glucose. $\mathbf{k}$ Effect of TA $(n=9)$ on the membrane plateau potential during active phase, in presence of glucose. The experiments were performed on ten preparations of mice islets. Friedman test on $\mathbf{f}, P=$ 0.05 ; repeated measures ANOVA test on $\mathbf{k}, P=6.88 \times 10^{-10} . * P<0.05$, $* * * P<0.001$ vs. $2.8-\mathrm{mM}$ glucose condition; ${ }^{\circ} P<0.01,{ }^{\circ 0} P<0.001$ vs. 16.7-mM glucose condition (paired Student's $t$ tests in $\mathbf{c}-\mathbf{e}, \mathbf{h}-\mathbf{j}$; Wilcoxon type tests with Dunn-Bonferroni correction in $\mathbf{f}$; least significant difference tests in $\mathbf{k}$ )

Glucose depolarized rat $\beta$-cells from an average resting potential of $-70.43 \pm 1.00 \mathrm{mV}$ to an average potential of $-36.12 \pm$ $1.52 \mathrm{mV}\left(n=15, P=3.99 \times 10^{-11}\right.$, paired $t$ test $)$. The main
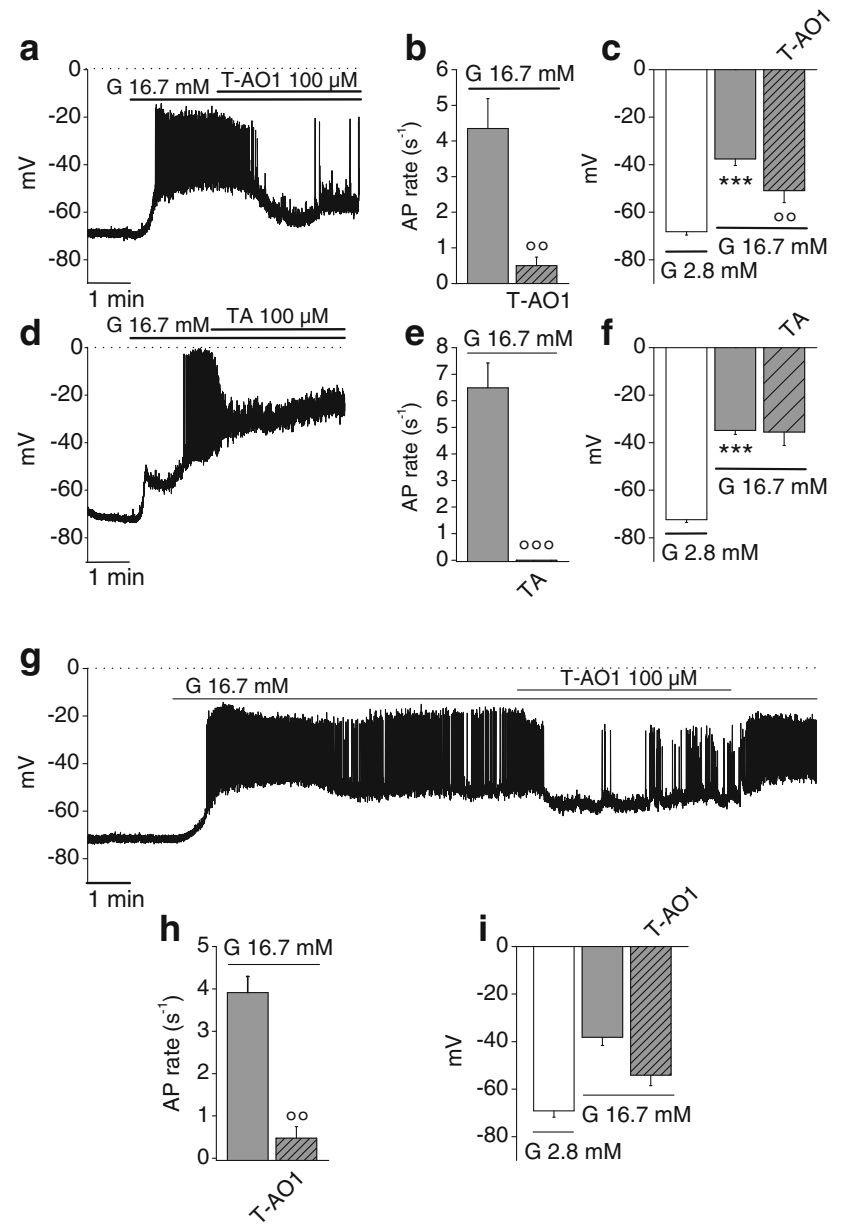

Fig. 4 Effect of Ano1 inhibitors on the membrane potential of $16.7 \mathrm{mM}$ glucose-stimulated murine dispersed $\beta$-cells. Zero-current nystatinperforated patch-clamp voltage recordings performed on dispersed $\beta$ cells stimulated with $16.7 \mathrm{mM}$ glucose before incubation with T-AO1 or TA $(100 \mu \mathrm{M})$ in the bathing medium. Sampling rate, $18 \mathrm{kHz} ; 2-\mathrm{kHz}$ filter setting. Dotted lines represent zero-voltage level. a-f Experiments carried out on rat dispersed $\beta$-cells, $n=7$ from three preparations of rat dispersed islet cells in presence of T-AO1 and $n=8$ from two preparations of rat dispersed islet cells with TA. a Representative recording \pm T-AO1. Effect of T-AO1 b on AP rate and $\mathbf{c}$ on average membrane potential. $\mathbf{d}$ Representative recording \pm TA. Effect of TA $\mathbf{e}$ on AP rate and $\mathbf{f}$ on average membrane potential. $\mathbf{g}-\mathbf{i}$ Experiments carried out on mice dispersed $\beta$ cells, $n=4$ from one preparation of mice dispersed islet cells. $\mathbf{g}$ Representative recording \pm T-AO1. Effect of T-AO1 $\mathbf{h}$ on AP rate and $\mathbf{i}$ on average membrane potential. Repeated measures ANOVA test on $\mathbf{c}$, $P=0.00123$; f, $P=2 \times 10^{-4}$; Friedman test on i, $P=0.18 . * * * P<0.001$ vs. $2.8 \mathrm{mM}$ glucose condition; ${ }^{\circ} P<0.01,{ }^{\circ} \mathrm{o} P<0.001$ vs. $16.7 \mathrm{mM}$ glucose condition (least significant difference tests in $\mathbf{c}$, f; paired Student's $t$ tests in $\mathbf{b}, \mathbf{e}, \mathbf{h}$ )

modification in the oscillatory pattern in presence of the inhibitors occurred in AP. The AP rate was drastically reduced from $4.35 \pm 0.84$ to $0.50 \pm 0.24 \mathrm{~s}^{-1}$, i.e., by $90.3 \pm 3.3 \%$ in presence of T-AO1 (Fig. 4b, $n=7, P=0.00128$ ), or inhibited by $100 \%$ in presence of TA (Fig. $4 \mathrm{e}, n=8, P=2,19 \times 10^{-4}$ ). The average AP rate measured on the stimulated cells was $5.49 \pm 0.67 \mathrm{~s}^{-1}(n=15)$. T-AO1 partially repolarized the glucose-stimulated cell from a potential of $-37.61 \pm 2.70$ to 
$-50.94 \pm 4.97 \mathrm{mV}$, thus by $13.33 \pm 2.58 \mathrm{mV}$ (Fig. $4 \mathrm{c}, n=7, P=$ 0.00209 ), while TA did not (Fig. 4f, $-34.82 \pm 1.65 \mathrm{mV}$ in its absence, $-35.48 \pm 5.69 \mathrm{mV}$ in its presence; $n=8, P=0.907$ ). Similar effects were observed in mice $\beta$-cells: glucose $(16.7 \mathrm{mM}$ ) depolarized the cell from $-69.12 \pm 2.64 \mathrm{mV}$ (resting potential at $2.8 \mathrm{mM}$ glucose) to $-38.17 \pm 3.46 \mathrm{mV}(n=4)$. T-AO1 quite potently and significantly reduced AP rate from $3.91 \pm 0.38$ to $0.48 \pm 0.27 \mathrm{~s}^{-1}$, i.e., by $87.4 \pm 7.2 \%$ (Fig. $4 \mathrm{~h}, n=$ $4, P=0,00602)$. T-AO1 repolarized the cell from $-38.17 \pm 3.47$ to $-54.10 \pm 4.44 \mathrm{mV}$, thus by $15.94 \pm 5.96 \mathrm{mV}$, although this effect did not reach statistical significance threshold (Fig. 4i, $n=4)$. Interestingly, the washout of T-AO1 inhibitor seemed to reverse its effects (with restored spiking activity), while the effect of TA did not show any recovery during the period of observation (Figs. $3 \mathrm{~g}$ and $4 \mathrm{~g}$ ).

\section{Chloride currents from rat $\beta$-cells (inside-out excised macropatches and whole cell) display Ano1 properties}

Figure 5 shows $\mathrm{Cl}^{-}$current recordings from excised macropatches and from whole cell performed on rat $\beta$-cells. These currents depend on the number of channels within the patch and on their open probability. At $0 \mu \mathrm{M} \mathrm{Ca}^{2+}$ with $\mathrm{Cl}^{-}$as only permeant ion (symmetrical $150 \mathrm{mM} \mathrm{NMDG-Cl} \mathrm{[78]),} \mathrm{no}$ currents were observed (Fig. $5 \mathrm{a}$ on excised patches, Fig. $5 \mathrm{n}$ on whole cell). At $1 \mu \mathrm{M} \mathrm{Ca}^{2+}$, outwardly rectifying $\mathrm{Cl}^{-}$currents were observed. The outward currents were composed of a small instantaneous time-independent component and a large slowly activating time-dependent component (Fig. 5b on single excised patches and 50 on whole cell). At $2 \mu \mathrm{M} \mathrm{Ca}^{2+}$, the main component of the current became instantaneous and time-independent. The inward and outward $\mathrm{Cl}^{-}$currents reached steady-state quasi-instantaneously and became almost symmetrical so that the current-voltage relationship became approximately linear (Fig. 5c, f, g, i on single excised patches). Thus, in rat $\beta$-cells, $\mathrm{Cl}^{-}$currents critically depend on $\left[\mathrm{Ca}^{2+}\right]_{\mathrm{i}}$ which is a characteristic of CaCCs [22,39]. The permeability sequence of monovalent anions, which is also characteristic by $\mathrm{CaCCs}$, was analyzed in whole-cell experiments replacing extracellular $150 \mathrm{mM}$ NMDG-Cl by equimolar NMDG-NO or NMDG-Br. Pipette solution contained $150 \mathrm{mM}$ NMDG-Cl and $1 \mu \mathrm{M} \mathrm{Ca}^{2+}$ (neither cyclic AMP (cAMP) nor ATP). An agar- $\mathrm{KCl} 3 \mathrm{M}$ salt bridge provided the junction between the $\mathrm{Ag} / \mathrm{AgCl}$ reference electrode and the bath. Permeability ratios $\left(\mathrm{P}_{\mathrm{X}} / \mathrm{P}_{\mathrm{Cl}}\right)$ of nitrate and bromide anions were calculated from the shifts of the reversal potentials using Goldman, Hodgkin, and Katz equation. The currents observed were outwardly rectifying. Replacing NMDG-Cl by NMDG-NO $\mathrm{NO}_{3}$ increased the current amplitude at positive potentials and shifted the reversal potentials toward negative potentials from $-0.71 \pm$ 0.91 to $-16.65 \pm 1.34 \mathrm{mV}$ (Fig. 5 j, k, top, $n=11, P=8.33 \times$ $10^{-7}$ ), i.e., by $-15.94 \pm 1.49 \mathrm{mV}$. Replacing NMDG-Cl by NMDG-Br had similar effects but shifted the reversal potentials toward less negative potentials from $-0.38 \pm 1.09$ to $-9.66 \pm 1.51 \mathrm{mV}$ (Fig. 51, k, bottom, $n=9, P=6.5 \times 10^{-5}$ ), i.e., by $-9.28 \pm 1.23 \mathrm{mV}$. The relative permeabilities $\left(\mathrm{P}_{\mathrm{x}} / \mathrm{P}_{\mathrm{Cl}}\right)$ of these anions were thus $\mathrm{NO}_{3}^{-}(1.83 \pm 0.10)>\mathrm{Br}^{-}(1.42 \pm 0.07)$ $>\mathrm{Cl}^{-}$(1.0) (Fig. 5m) consistent with the values reported for endogenous CaCCs and Ano1-transfected cells [22, 39, 78]. We then investigated the effects of blocking Anol on the $\mathrm{Cl}^{-}$ currents. In these experiments, pipette and bath solutions contained $150 \mathrm{mM}$ NMDG-Cl. On inside-out excised macropatches, $10 \mu \mathrm{M}$ T-AO1 in the pipette solution preincubated for $5 \mathrm{~min}$ abolished $2 \mu \mathrm{M} \mathrm{Ca}^{2+}$-activated $\mathrm{Cl}^{-}$currents at $+100 \mathrm{mV}$ (Fig. 5a, c, e, f; currents at $2 \mu \mathrm{M} \mathrm{Ca}^{2+}: 226.10 \pm$ $47.39 \mathrm{pA}, n=8$; with T-AO1: $19.73 \pm 4.32 \mathrm{pA}, n=12, P=0.019$ which is not different from current at $0 \mu \mathrm{M} \mathrm{Ca}^{2+}: 6.80 \pm$ $0.94 \mathrm{pA}, n=12, P=0.071)$. Blocking Anol antibodies ab72984 1:100 [14] in the pipette solution (extracellular side of the patch) preincubated for 4 min totally abolished $2 \mu \mathrm{M}$ $\mathrm{Ca}^{2+}$-activated $\mathrm{Cl}^{-}$currents at $+100 \mathrm{mV}$ compared with boiled ab72984 1:100 in the pipette (Fig. 5a, g-i; control current at $2 \mu \mathrm{M} \mathrm{Ca}^{2+}$ with boiled antibody: $191.59 \pm 17.75 \mathrm{pA}, n=18 \mathrm{vs}$. with active antibody: $15.44 \pm 4.01 \mathrm{pA}, n=13, P<0.001$ which is not different from current at $0 \mu \mathrm{M} \mathrm{Ca}^{2+}, P>0.999$ ). Wholecell current activated by $1 \mu \mathrm{M} \mathrm{Ca}^{2+}$ in the pipette was similarly strongly inhibited in the presence of $10 \mu \mathrm{M}$ T-AO1 (bath) for 2 min (Fig. $5 \mathrm{n}-\mathrm{q} ; 1 \mu \mathrm{M} \mathrm{Ca}^{2+}$-activated control normalized current at $+100 \mathrm{mV}: 451.93 \pm 52.71 \mathrm{pA} / \mathrm{pF}, n=$ 21; with T-AO1: $98.78 \pm 15.31 \mathrm{pA} / \mathrm{pF}, n=15, P=0.001)$. In whole-cell experiments, ab72984 in the pipette (cytosolic side) always reduced $1 \mu \mathrm{M} \mathrm{Ca}^{2+}$-activated $\mathrm{Cl}^{-}$currents at + $100 \mathrm{mV}$ measured at different times (Fig. $5 \mathrm{r}-\mathrm{t}$; boiled vs. active antibody at $6 \mathrm{~min}: 436.61 \pm 29.03 \mathrm{pA} / \mathrm{pF}, n=14 \mathrm{vs}$. $194.48 \pm 29.03 \mathrm{pA} / \mathrm{pF}, n=13, P=1.26 \times 10^{-4}$; at $8 \mathrm{~min}$ : $379.48 \pm 34.72 \mathrm{pA} / \mathrm{pF}, n=12$ vs. $147.71 \pm 16.01 \mathrm{pA} / \mathrm{pF}, n=12$, $P=4 \times 10^{-6}$; at $10 \mathrm{~min}: 258.06 \pm 25.37 \mathrm{pA} / \mathrm{pF}, n=10$ vs. 114.82 $\pm 10.69 \mathrm{pA} / \mathrm{pF}, n=10, P=2.15 \times 10^{-4}$; at $12 \mathrm{~min}: 223.33 \pm$ $45.20 \mathrm{pA} / \mathrm{pF}, n=5$ vs. $101.60 \pm 10.05 \mathrm{pA} / \mathrm{pF}, n=8, P=0.007)$.

\section{Single-channel $\mathrm{Cl}^{-}$currents from inside-out patches isolated from rat $\beta$-cells are consistent with Ano1 currents}

In the absence of $\mathrm{Ca}^{2+}$ in the bathing medium, no current was observed, while $1 \mu \mathrm{M} \mathrm{Ca}^{2+}$ activated single-channel $\mathrm{Cl}^{-}$current (filled pipette resistance $20 \mathrm{M} \Omega$ ). Representative single-channel $\mathrm{Cl}^{-}$current recordings are shown in Fig. 6a; their amplitude was calculated by Gaussian fit to all-point histograms of recordings at a sampling rate of $5 \mathrm{kHz}$ (Fig. 6b). The observed amplitudes of single-channel $\mathrm{Cl}^{-}$currents were small, as also described for $\mathrm{CaCCs}$ by Nilius et al. [49, 50]. The single-channel currentvoltage relationship (which plots the amplitude of one channel independently of its open probability vs. voltage) was linear $(r=$ $0.989, P<0.0001$, Fig. 6c). Its slope, i.e., the single-channel conductance $(\gamma=8.37 \pm 0.15 \mathrm{pS})$, exactly matches the conductance described for Ano1 in similar conditions in transfected 


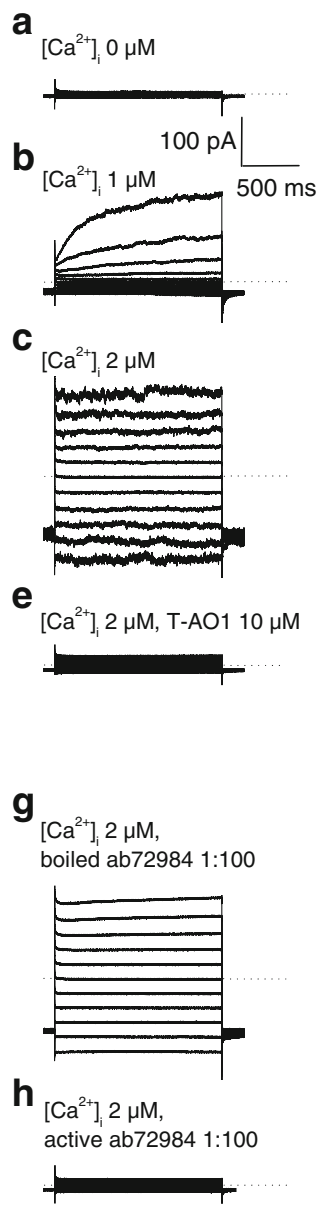

d
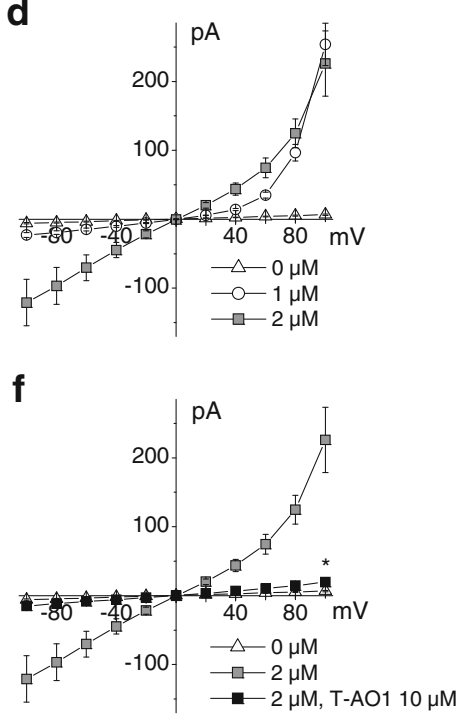

i

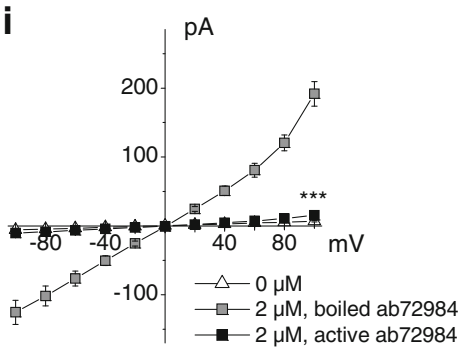

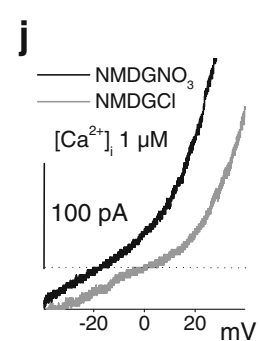

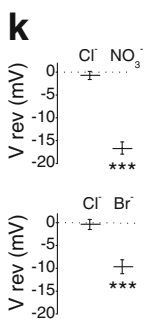

I

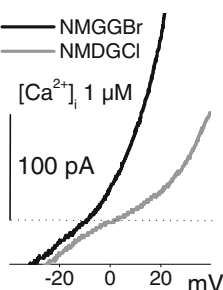

m

n
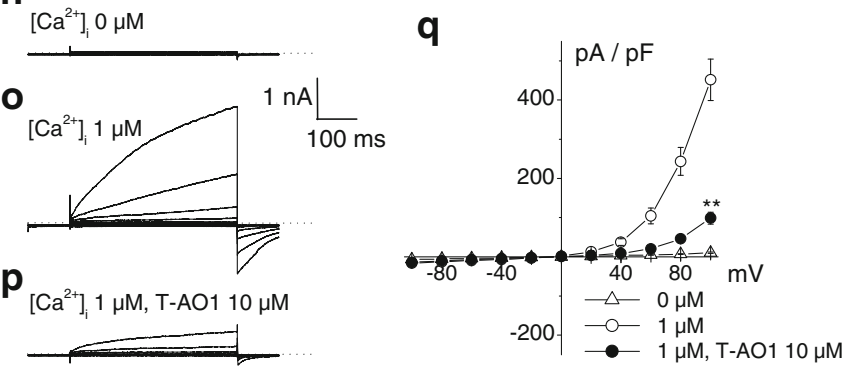

$\mathbf{r}$ $+100 \mathrm{mV}$, boiled ab72984 (pipette)

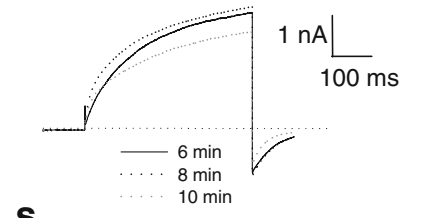

$\mathbf{s}$ $+100 \mathrm{mV}$, active ab72984

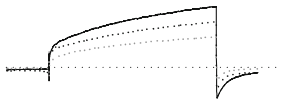

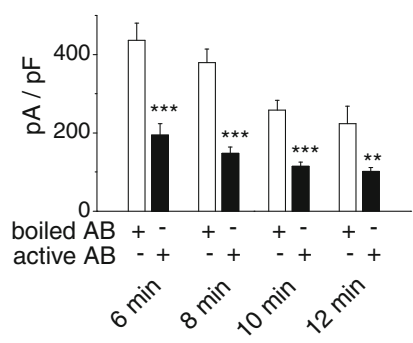

$\left[\mathrm{Ca}^{2+}\right]_{i} 1 \mu \mathrm{M}$

Fig. 5 Chloride currents from rat $\beta$-cells (inside-out excised macropatches and whole cell). $\mathbf{a}-\mathbf{i}$ Chloride currents from inside-out single excised patches. Pipette and bath solutions contained $150 \mathrm{mM}$ NMDG-Cl. Sampling rate, $25 \mathrm{kHz} ; 2-\mathrm{kHz}$ filter setting. Filled pipette resistance, $5 \mathrm{M} \Omega$. Current traces recorded were induced by $1500-\mathrm{ms}$ voltage steps from -100 to $+100 \mathrm{mV}$, spaced $20 \mathrm{mV}$ (holding potential, $-70 \mathrm{mV}, 200 \mathrm{~ms}$ before and after each step). Dotted lines indicate zerocurrent level. a-c Representative recordings of $\mathrm{Cl}^{-}$currents. The cytosolic face was exposed to bath solutions with different $\left[\mathrm{Ca}^{2+}\right]$ : $0 \mu \mathrm{M}$ in $\mathbf{a}, 1 \mu \mathrm{M}$ in $\mathbf{b}$, and $2 \mu \mathrm{M}$ in c. d Steady-state current-voltage relationships of $\mathrm{Cl}^{-}$currents at $0 \mu \mathrm{M} \mathrm{Ca}^{2+}(n=12), 1 \mu \mathrm{M} \mathrm{Ca}^{2+}(n=5)$, and $2 \mu \mathrm{M} \mathrm{Ca}^{2+}(n=8)$. e Representative recording of $\mathrm{Cl}^{-}$currents stimulated by $2 \mu \mathrm{M} \mathrm{Ca}^{2+}$ in the presence of T-AO1 $10 \mu \mathrm{M}$ in the pipette. $\mathbf{f}$ Steadystate current-voltage relationships of $\mathrm{Cl}^{-}$currents at $2 \mu \mathrm{M} \mathrm{Ca}^{2+}$ in the absence $(n=8)$ or presence $(n=12)$ of T-AO1 $10 \mu \mathrm{M}$ in the pipette and at $0 \mu \mathrm{M} \mathrm{Ca}^{2+}(n=12)$. g, h Representative recordings of $\mathrm{Cl}^{-}$currents stimulated by $2 \mu \mathrm{M} \mathrm{Ca}^{2+}$, respectively, in the presence of boiled or active blocking Ano1 antibodies ab72984 1:100 in the pipette. i Steadystate current-voltage relationships of $\mathrm{Cl}^{-}$currents at $2 \mu \mathrm{M} \mathrm{Ca}^{2+}$ in the presence of boiled $(n=18)$ or active $(n=13)$ blocking Ano1 antibodies ab72984 1:100 in the pipette and at $0 \mu \mathrm{M} \mathrm{Ca}^{2+}(n=12)$. j-t Whole-cell $\mathrm{Cl}^{-}$currents from dispersed $\beta$-cells. Pipette and bath solutions contained $150 \mathrm{mM}$ NMDG-Cl except in anion selectivity experiments where the bath $\mathrm{Cl}^{-}$was replaced by $\mathrm{NO}_{3}{ }^{-}$or $\mathrm{Br}^{-}$for repeated measures. Sampling rate, 10 or $25 \mathrm{kHz}$; $2 \mathrm{kHz}$ filter setting. Filled pipette resistance, $5 \mathrm{M} \Omega$. Dotted lines indicate zero current or $\mathrm{P}_{\mathrm{x}} / \mathrm{P}_{\mathrm{Cl}}=1$ level. $\mathbf{j}$, I Representative current traces from $\beta$-cells induced by voltage ramps $(20 \mathrm{mV} / \mathrm{s})$ at $1 \mu \mathrm{M}$

$\mathrm{Ca}^{2+}$ (pipette). Bath NMDG-Cl solution was replaced by either NMDG$\mathrm{NO}_{3}$ in $\mathbf{j}$ or NMDG-Br in $\mathbf{l}$. $\mathbf{k}$ Nitrate and bromide anions shift the reversal potential (V rev) toward negative values ( $n=11$ and 9 , respectively). $\mathbf{m}$ Permeability ratios $\left(\mathrm{P}_{\mathrm{x}} / \mathrm{P}_{\mathrm{Cl}}\right)$ of nitrate and bromide anions calculated from the shifts of the reversal potentials in $\mathbf{k}$ using Goldman, Hodgkin, and Katz equation. n-t Current traces recorded were induced by $400-\mathrm{ms}$ voltage steps from -100 to $+100 \mathrm{mV}$, spaced $20 \mathrm{mV}$ (holding potential, $-70 \mathrm{mV}, 100 \mathrm{~ms}$ before and after each step). n-p Representative recordings of whole-cell $\mathrm{Cl}^{-}$currents at $0 \mu \mathrm{M} \mathrm{Ca}^{2+}$ in $\mathbf{n}, 1 \mu \mathrm{M}$ in $\mathbf{o}$, and $1 \mu \mathrm{M}$ in the presence of T-AO1 $10 \mu \mathrm{M}$ in the bath medium in $\mathbf{p .} \mathbf{q}$ Normalized current-voltage relationships of whole-cell $\mathrm{Cl}^{-}$currents at $1 \mu \mathrm{M} \mathrm{Ca}^{2+}$ in the absence $(n=21)$ or presence $(n=15)$ of T-AO1 $10 \mu \mathrm{M}$ in the bath medium and at $0 \mu \mathrm{M} \mathrm{Ca}{ }^{2+}(n=14)$. r, s Representative recordings of whole-cell $\mathrm{Cl}^{-}$currents evoked by $1 \mu \mathrm{M} \mathrm{Ca}^{2+}$ at + $100 \mathrm{mV}$ after 6-, 8-, and 10-min membrane rupture in the presence of boiled Ano1 antibodies ab72984 1:100 in the pipette (r) or active Ano1 antibodies ab72984 1:100 in the pipette (s). t Normalized whole-cell $\mathrm{Cl}^{-}$ currents evoked by $1 \mu \mathrm{M} \mathrm{Ca}^{2+}$ at the end of the $+100-\mathrm{mV}$ voltage step in the presence of boiled Anol antibodies ab72984 1:100 or active Ano1 antibodies ab72984 1:100 in the pipette after $6 \mathrm{~min}(n=14$ and 13), $8 \mathrm{~min}$ $(n=12$ and 12), $10 \min (n=10$ and 10$)$, and $12 \min (n=5$ and 8$)$ membrane rupture. Experiments of Fig. 5 were carried out on six preparations of rat dispersed islet cells. Kruskal-Wallis tests on $\mathbf{f}, \mathbf{i}, \mathbf{q}$, $P<0.001, * P<0.05, * * P<0.01, * * * P<0.001$ vs. control (MannWhitney-type tests with Dunn-Bonferroni correction in $\mathbf{f}, \mathbf{i}, \mathbf{q}$, paired Student's $t$ tests in $\mathbf{k}$, independent Student's $t$ tests in $\mathbf{t}$ ) 
a

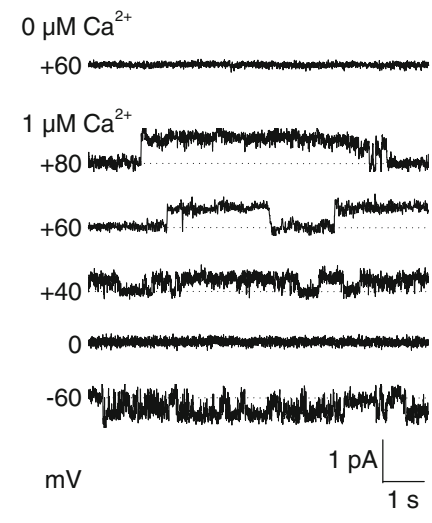

C

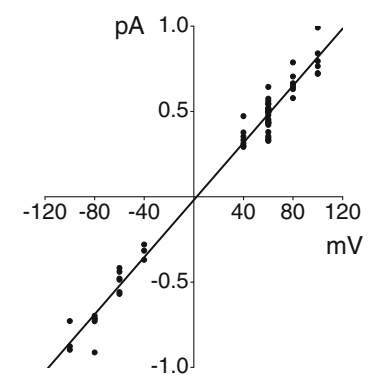

b
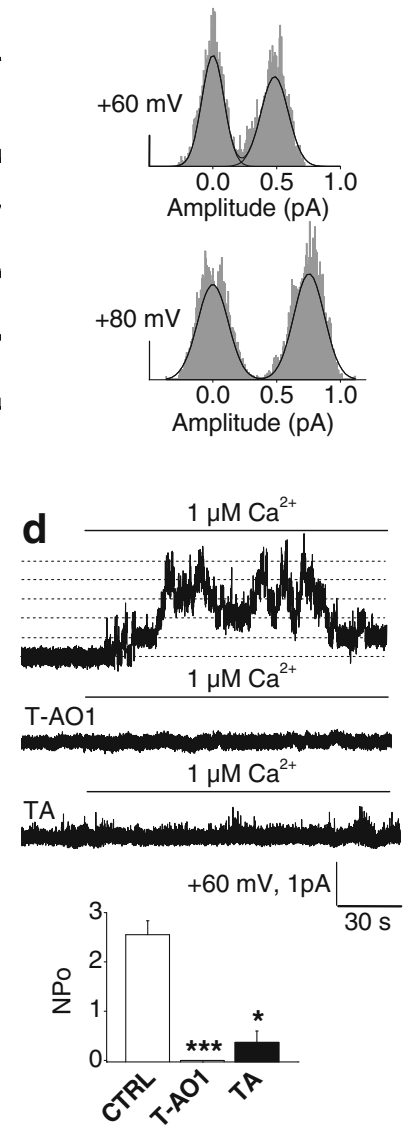

Fig. 6 Single-channel $\mathrm{Cl}^{-}$currents from inside-out patches excised from rat $\beta$-cells. Pipette and bath solutions contained $150 \mathrm{mM} \mathrm{NMDG-Cl}$; pipette contained also $10 \mu \mathrm{M}$ nifedipine and $10 \mu \mathrm{M}$ glibenclamide. Sampling rate, $5 \mathrm{kHz} ; 1-\mathrm{kHz}$ filter setting; $100-\mathrm{Hz}$ final digital filtration. Filled pipette resistance, $20 \mathrm{M} \Omega$. Dotted lines indicate zerocurrent or single-channel levels. a Representative recordings. Singlechannel currents are activated by $1 \mu \mathrm{M} \mathrm{Ca}^{2+}$ in the bathing solution. b Representative number of events-amplitude histograms at +60 and + $80 \mathrm{mV}$. Single-channel amplitudes were obtained from Gaussian fit. The scale bars indicate 250 events. c Current-voltage relationship of single-channel $\mathrm{Cl}^{-}$currents activated by $\mathrm{Ca}^{2+}$. A single-channel conductance $(\gamma)$ of $8.37 \pm 0.15 \mathrm{pS}$ was calculated from a linear fit $(r=$ $0,989, P<0.0001)$ on all the points $(n=65:+100 \mathrm{mV}, n=6 ;+80 \mathrm{mV}, n=$ $7 ;+60 \mathrm{mV}, n=28 ;+40 \mathrm{mV}, n=7 ;-40 \mathrm{mV}, n=3 ;-60 \mathrm{mV}, n=6 ;-80 \mathrm{mV}$, $n=5 ;-100 \mathrm{mV}, n=3$ experiments performed on six preparations of rat dispersed islet cells). $\mathbf{d}$ Time course of channel activity before and during exposure to $1 \mu \mathrm{M} \mathrm{Ca}^{2+}$ in the absence of inhibitors $(n=5)$, in the presence of T-AO1 $100 \mu \mathrm{M}(n=7)$ and in the presence of TA $100 \mu \mathrm{M}(n=6)$ in the pipette solution at $+60 \mathrm{mV}$. Upper panel: representative recordings in presence (or not) of the inhibitors. Lower panel: mean NPo $( \pm \mathrm{SEM})$ values, i.e., the product of the number of channels in a patch $(N)$ by the open probability $(\mathrm{Po})$, calculated for $2 \mathrm{~min}$, after 15 -s stimulation with $\mathrm{Ca}^{2+}$. The $n$ experiments were performed on two preparations of rat dispersed islet cells. Kruskal-Wallis test on d, $P<0.001,{ }^{*} P<0.05$, $* * * P<0.001$ vs. control (Mann-Whitney-type tests with DunnBonferroni correction)

Ano1/ET $\mathrm{A}$ R-HEK 293 cells [78]. The channel open probability was more important at positive voltages and decreased toward negative potentials, a well-known characteristic of $\mathrm{CaCCs}[49$,

50], as confirmed by outwardly rectifying whole-cell and excised macropatch $\mathrm{Cl}^{-}$currents activated by $1 \mu \mathrm{M} \mathrm{Ca}^{2+}$ (Fig. 5b, o). The effect of the inhibitors T-AO1 and TA, considered as specific for Ano1 [47, 48], was evaluated by measuring their effect on $N P o$ at $+60 \mathrm{mV}$ (Fig. 6d). The inhibitors were added in the pipette solution before sealing. NPo was calculated for $2 \mathrm{~min}$ after 15-s stimulation with $1 \mu \mathrm{M} \mathrm{Ca}^{2+}$. For control patches, $N P O$ was $2.55 \pm 0.28(n=5)$. In presence of T-AO1, no opening was observed $(n=7, P<0.001)$, and with TA, NPo drastically decreased to $0.36 \pm 0.23(n=6, P=0.0041)$. The abolishment of single-channel $\mathrm{Cl}^{-}$current attests that Anol is indeed the target affected by these inhibitors. Recordings were validated only when patches showed one or a few single-channel events at the beginning of the measurements (immediately after excision, i.e., shortly after $\mathrm{NaCl}$ medium containing $1-\mathrm{mM} \mathrm{Ca}^{2+}$ replacement) or at $+100 \mathrm{mV}$ at the end of recordings.

\section{Effect of Ano1 inhibitors on whole-cell $\mathrm{Ba}^{2+}$ currents from rat dispersed $\beta$-cells}

Although the current evidence points to a specific effect on $\mathrm{Cl}^{-}$ channels, it could still be argued that these inhibitors directly affect also the opening of L-type $\mathrm{Ca}^{2+}$ channels. Whole-cell $\mathrm{Ba}^{2+}$ current is representative of $\mathrm{Ca}^{2+}$ current mediated by Ltype $\mathrm{Ca}^{2+}$ channels. $\mathrm{Ba}^{2+}$ currents were recorded during 200$\mathrm{ms}$ depolarizations to $-10 \mathrm{mV}$ from a holding potential of $-70 \mathrm{mV}$ in the presence (or not) of T-AO1, TA, or nifedipine in the bathing medium (Fig. 7a). Note that a rundown of the currents occurred after a few stimulations [2]. Nifedipine largely inhibited the current (Fig. 7a, b). The appearance of the current $(I)$-voltage $(V)$ relationship (Fig. 7c) together with the nifedipine inhibition thereby confirms the implication of L-type $\mathrm{Ca}^{2+}$ channels as mediators of these $\mathrm{Ba}^{2+}$ currents [2, 59, 60, 77]. Figure 7b summarizes the normalized whole-cell peak inward $\mathrm{Ba}^{2+}$ currents observed in the same conditions as in Fig. 7a. Control value averaged $-35.60 \pm 3.49 \mathrm{pA} / \mathrm{pF}(n=27)$. Neither T-AO1 nor TA had any inhibitory effect on the $\mathrm{Ba}^{2+}$ current: T-AO1-exposed cells exhibited average current values of $-40.84 \pm 6.09 \mathrm{pA} / \mathrm{pF}$ $(n=17$ cells, $P>0.5)$, and cells perfused in presence of TA, $-39.21 \pm 6.51 \mathrm{pA} / \mathrm{pF}(n=16, P>0.5)$. Nifedipine quite potently and significantly reduced the current to $27.7 \pm 3.9 \%$ of the average control value, i.e., $-9.85 \pm 1.37 \mathrm{pA} / \mathrm{pF}(n=17, P<0.001)$. The average cell capacitance was $7.66 \pm 0.35 \mathrm{pF}(n=77)$.

\section{Effect of reduced intracellular $\mathrm{Cl}^{-}$and $\mathrm{HCO}_{3}{ }^{-}$ on membrane potential oscillations in dispersed $\beta$-cells}

The last series of experiments aimed at investigating the possible role of Ano1 in the exit of bicarbonate anions from islet cells. To reduce intracellular $\mathrm{Cl}^{-}$and $\mathrm{HCO}_{3}{ }^{-}$, we used here an incubation medium containing no $\mathrm{HCO}_{3}{ }^{-}$and low $\mathrm{Cl}^{-}$concentration $(20 \mathrm{mM})$ with bumetanide $(200 \mu \mathrm{M})$, the latter preventing $\mathrm{Cl}^{-}$recycling through the $\mathrm{Na}^{+}-\mathrm{K}^{+}-2 \mathrm{Cl}^{-}$- 


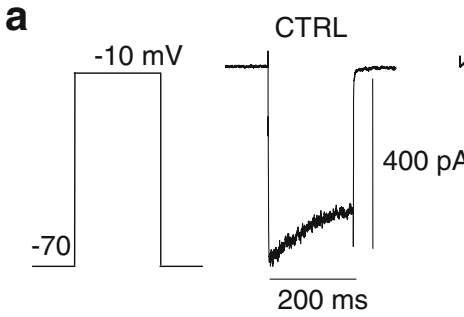

b

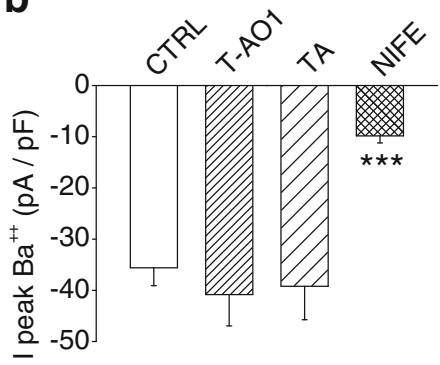

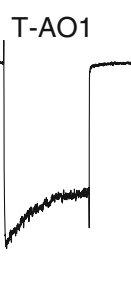

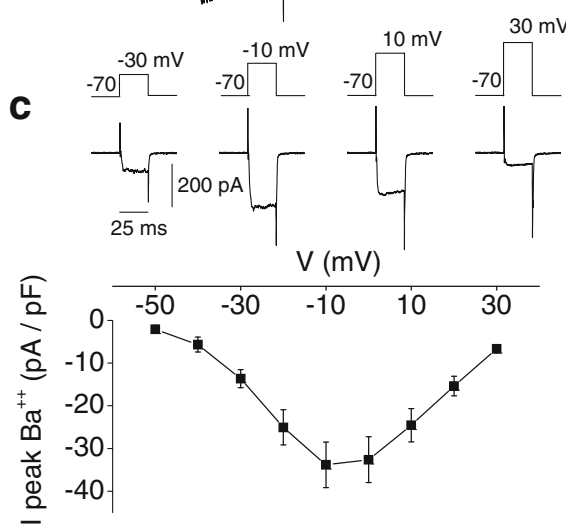

whole-cell peak $\mathrm{Ba}^{2+}$ currents observed with the same protocol as in a. For control experiments, $n=27$. While T-AO1 $(n=17)$ and TA $(n=16)$ had no effect on the $\mathrm{Ba}^{2+}$ current, nifedipine potently reduced it $(n=17)$. $\mathbf{c}$ Normalized whole-cell peak inward $\mathrm{Ba}^{2+}$ current-voltage relation observed during 25-ms depolarization. Voltage steps were applied from a holding potential of $-70 \mathrm{mV}, n=6$. The current values were corrected for leakage and capacity currents. Experiments of these sets were carried out on two preparations of rat dispersed islet cells. Kruskal-Wallis test on $\mathbf{b}$, $P<0.001, * * * P<0.001$ vs. control (Mann-Whitney-type tests with Dunn-Bonferroni correction)

alternates repetitive phases of depolarized plateau potential (slow waves) on top of which $\mathrm{Ca}^{2+}$-dependent AP superimposes ("active phase") with partially repolarized silent phases [15-17, 31]. Variations in membrane potential are instrumental in inducing $\mathrm{Ca}^{2+}$ variations $[5,59,61]$, hence insulin release. Importantly, insulin release is sustained only when these membrane potential fluctuations are also sustained $[7,24,30]$. Glucose also induces an increase in ${ }^{36} \mathrm{Cl}^{-}$efflux from mice islet $\beta$-cells. Severe reduction in this efflux by incubation in low $\mathrm{Cl}^{-}$media inhibited the electrical bursting pattern together with the ${ }^{45} \mathrm{Ca}^{2+}$ uptake and, therefore, the glucose-stimulated insulin secretion $[65,67]$. This glucose-induced $\mathrm{Cl}^{-}$efflux from rat pancreatic islet $\beta$-cells increases in proportion to the extracellular glucose concentration in the range of 6 to $20 \mathrm{mM}$ [43].

The present experiments were undertaken to find out whether the observed $\mathrm{Cl}^{-}$and possibly $\mathrm{HCO}_{3}{ }^{-}$efflux from rat pancreatic islet $\beta$-cells are mediated by Ano1. As a first approach, we demonstrated the expression of Anol in rat pancreatic islet $\beta$-cells by RT-PCR (including sequence analysis), immunohistochemistry (including inhibition of labeling by Ano1 synthetic peptide), and western blotting (Fig. 1). Of interest, transcripts of the expected size of Ano1 were also found in preparations from human pancreatic tissue, thus
The $\beta$-cell is an excitable cell in which raising glucose concentration above a threshold value of 5.5-6 $\mathrm{mM}$ induces a characteristic fluctuating electrical activity. This cyclic pattern 

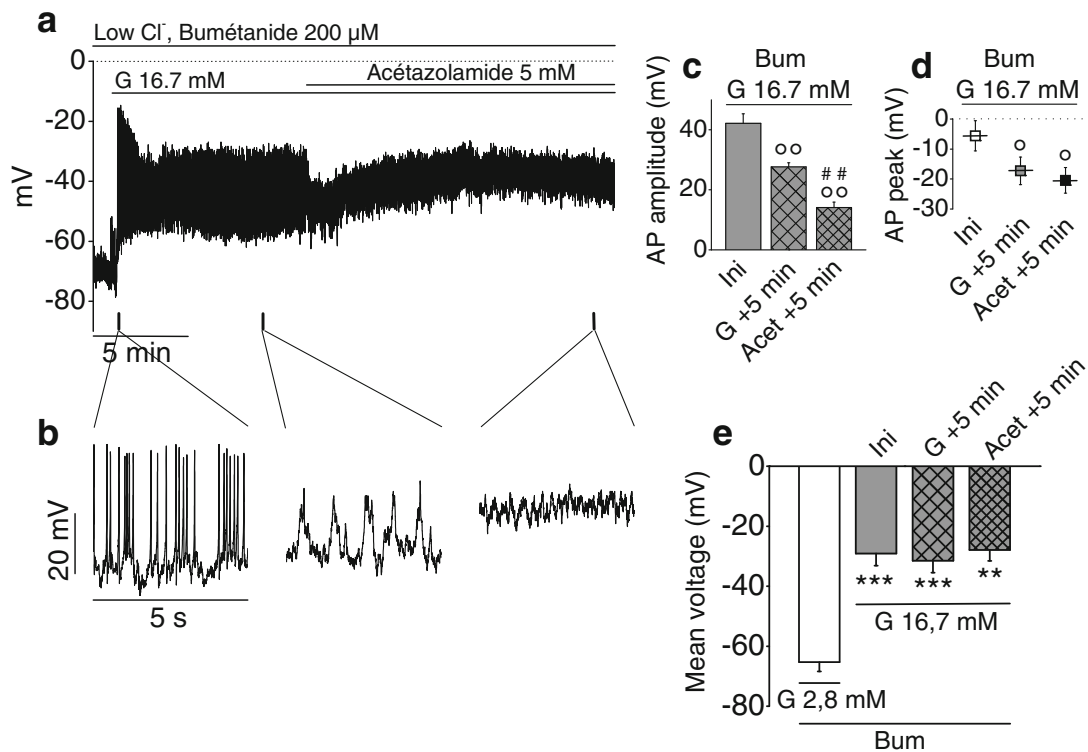

Fig. 8 Effect of glucose on membrane potential oscillations in single rat $\beta$-cells exposed to low $\mathrm{Cl}^{-} / \mathrm{HCO}_{3}{ }^{-}$-free medium. Zero-current nystatinperforated patch-clamp voltage recordings. Sampling rate, $18 \mathrm{kHz} ; 2-\mathrm{kHz}$ filter setting. Dotted lines represent zero-voltage level. $\beta$-Cells were continuously exposed to $200 \mu \mathrm{M}$ bumetanide (Bum), a NKCC1/2 inhibitor, and stimulated with $16.7 \mathrm{mM}$ glucose $(\mathrm{G} 16.7 \mathrm{mM})$ in Hepesbuffered $\mathrm{NaCl}$ solution without bicarbonate containing $20 \mathrm{mM} \mathrm{Cl}^{-}$. After 10-min glucose stimulation, $5 \mathrm{mM}$ acetazolamide (Acet), a carbonic anhydrase inhibitor, was added to further reduce intracellular $\mathrm{HCO}_{3}{ }^{-}$. a Representative recording. b Extended timescale of recording a. c AP

suggesting that Ano1 is also expressed in human. As a second approach, we measured the effect of Ano1 inhibitors on GSIS. Exposure to $100 \mu \mathrm{M}$ T-AO1 totally prevented the increment of insulin secretion induced by 8.3 and $16.7 \mathrm{mM}$ glucose; exposure to TA was qualitatively similar with a complete inhibition at $8.3 \mathrm{mM}$ glucose but not total $(67 \%)$ at $16.7 \mathrm{mM}$ glucose. The concentration of inhibitors necessary to abolish GSIS was admittedly rather high, but this is probably merely related to diffusion into the center of islet where $\beta$-cells reside [33]. We therefore also looked at the effect of the blocking Ano1 antibodies ab72984 [14] which at 1:100 abolished 16.7 mM GSIS (Fig. 2 (c3)).

In $\beta$-cell, glucose induces a typical pattern of cyclic fluctuations of the membrane potential. Yet, while the rhythmic electrical activity of the heart evidenced in the electrocardiogram can be adequated to the gating of a series of wellidentified ionic channels [4], only a few channels have been well identified as critically involved and necessary for the glucose-induced fluctuations of the $\beta$-cell membrane potential. Glucose is absolutely necessary to induce these cyclic fluctuations as, when present below its threshold, the membrane potential remains quite stable at around $-70 \mathrm{mV}$. Three main phases can be individualized: (1) a slow depolarization ascribed to the closure of $\mathrm{K}_{\text {ATP }}$ channels reproduced by sulfonylurea drugs and inhibited by diazoxide, (2) cyclic waves of amplitude at various times, i.e., at the beginning of the spiking activity before rundown (Ini), after $5 \mathrm{~min}$ in presence of glucose stimulation $(\mathrm{G}+$ $5 \mathrm{~min}$ ), and after $5 \mathrm{~min}$ in presence of acetazolamide (Acet $+5 \mathrm{~min}$ ). d AP peak voltage at similar times. e Mean voltage at similar times. For all results, $n=6$ experiments performed on one preparation of rat islets. Repeated measures ANOVA test on c, $P=2.50 \times 10^{-5}$; d, $P=1.29 \times 10^{-4}$; and e, $P=7.42 \times 10^{-10}$. ** $P<0.01, * * * P<0.001$ vs. $2.8-\mathrm{mM}$ glucose condition in presence of bumetanide; ${ }^{\circ} P<0.05,{ }^{\circ} P<0.01$ vs. Ini; $\# \# P<0.01$ vs. $\mathrm{G}+5$ min (Sidak tests)

depolarization interrupted by silent phases of partial repolarization whose length decreases when glucose concentration raises, and (3) AP ascribed to the opening of L-type $\mathrm{Ca}^{2+}$ channels, inhibited by nifedipine. The last two phases are reminiscent of the pacing activity of interstitial cells of Cajal in the intestine $[35,79]$ except that glucose is absolutely required to induce this pacing activity in $\beta$-cell. A third objective of this study was to show that Ano1 mediates the cyclic waves of depolarization, which are absolutely necessary to reach the threshold of the L-type $\mathrm{Ca}^{2+}$ channels (triggering AP). These waves of depolarization can be at least partially attributed to the gating of Ano 1 (with $\mathrm{Cl}^{-}$exit from the $\beta$-cell), as exposure to T-AO1 or TA inhibitors almost totally suppressed AP or at least drastically reduced AP rate. The more potent T-AO1 partially repolarized the $\beta$-cell (Figs. 3 and 4). Drastic reduction in AP rate severely impairs insulin secretion (Figs. 2, 3, and 4). Furthermore, the inhibitors repolarized the AP peak which also plays a role in $\mathrm{Ca}^{2+}$ influx. Finally, TA reduced by one-third AP amplitude in mice $\beta$-cells from whole islet upon 16.7-mM glucose stimulation, while no more AP was observed in rat dispersed $\beta$-cells. A contrario, increased AP rate is known to raise $\mathrm{Ca}^{2+}{ }_{i}$ and insulin secretion by $\mathrm{SK} 4^{-/-}$mice [19]. Increased AP amplitude (with increased AP peak) observed by blocking large-conductance $\mathrm{Ca}^{2+}$-activated $\mathrm{K}^{+}$channel current $\left(\mathrm{I}_{\mathrm{BK}}\right)$ with paxillin significantly 
increased $\mathrm{Ca}^{2+}$ entry and insulin secretion [34], while reduction in AP amplitude by tetrodotoxin drastically reduced the stimulation of insulin secretion in human $\beta$-cells [10].

The presence of active Ano 1 channels in $\beta$-cells was demonstrated in inside-out excised patches and in conventional whole-cell patch-clamp experiments on dispersed cells. Chloride currents from rat $\beta$-cells display typical properties of CaCCs (Fig. 5). No $\mathrm{Cl}^{-}$current was observed in the absence of intracellular $\mathrm{Ca}^{2+}$ (symmetrical $150 \mathrm{mM}$ NMDG-Cl condition in the absence of cAMP and ATP). One-micromolar $\mathrm{Ca}^{2+}$ directly triggered strongly outwardly rectifying currents showing a large slowly activating time-dependent component, and this behavior completely changed to nearly linear at $2 \mu \mathrm{M}$ $\left[\mathrm{Ca}^{2+}\right]_{\mathrm{i}}$ with a large instantaneous, time-independent component. This different behavior depending on $\left[\mathrm{Ca}^{2+}\right]_{\mathrm{i}}$ is characteristic by CaCCs $[22,39]$ now identified as Ano1 [64]. The permeability sequence of monovalent anions, which is also characteristic by $\mathrm{CaCCs}$, was analyzed in whole-cell experiments $\left(1 \mu \mathrm{M}\left[\mathrm{Ca}^{2+}\right]_{\mathrm{i}}\right)$ replacing extracellular $150 \mathrm{mM}$ NMDG-Cl by equimolar NMDG-NO ${ }_{3}$ or NMDG-Br. Permeability ratios $\left(\mathrm{P}_{\mathrm{x}} / \mathrm{P}_{\mathrm{Cl}}\right)$ of nitrate and bromide anions calculated from the shifts of the reversal potentials using Goldman, Hodgkin, and Katz equation were $\mathrm{NO}_{3}{ }^{-}(1.83 \pm 0.10)>\mathrm{Br}^{-}$ $(1.42 \pm 0.07)>\mathrm{Cl}^{-}(1.0)$, consistent with those reported for endogenous CaCCs and Ano1-transfected cells [22, 39, 78]. The observed currents were outwardly rectifying, excluding cystic fibrosis transmembrane conductance Regulator (CFTR) currents. Furthermore, blocking Ano1 antibodies ab72984 [14] directed against the fifth and sixth transmembrane domains that constitute the pore-forming region and T-AO1 used at $10 \mu \mathrm{M}$ here directly in contact with the cell membrane completely abolished the $2 \mu \mathrm{M} \mathrm{Ca}^{2+}$-activated $\mathrm{Cl}^{-}$currents from inside-out excised macropatches from rat $\beta$-cell. A similar inhibitory effect of T-AO1 on $1 \mu \mathrm{M} \mathrm{Ca}^{2+}$-activated $\mathrm{Cl}^{-}$ currents was observed in whole-cell experiments. These observations prove that active Anol channels are present in the $\beta$-cell membrane. Finally, single-channel $\mathrm{Cl}^{-}$currents were examined in inside-out excised patches from rat $\beta$-cell membrane (Fig. 6). The activation of the channels was $\mathrm{Ca}^{2+}$-dependent, as in the absence of $\mathrm{Ca}^{2+}$ in the bath (cytoplasmic side), no current was observed. At $1 \mu \mathrm{M} \mathrm{Ca}^{2+}$, a unique $\mathrm{Cl}^{-}$ conductance was evoked. The channel involved exhibited a linear $I / V$ relationship, with a small slope conductance of 8.37 $\pm 0.15 \mathrm{pS}$ matching the Ano1 conductance reported under similar conditions (symmetrical $150 \mathrm{mM} \mathrm{NMDG-Cl)} \mathrm{[55,}$ 78]. Its opening (measured by NPo) was abolished in the presence of Ano1 inhibitors (T-AO1 or TA) [47, 48]. Again, these single-channel experiments were performed in absence of ATP, PKA, and cAMP and channel activation required $\mathrm{Ca}^{2+}$, excluding CFTR $[11,20]$ under these conditions although it has a nearly similar conductance $(10 \mathrm{pS})$.

L-type $\mathrm{Ca}^{2+}$ channels were not affected by Ano1 inhibitors, as shown by the whole-cell $\mathrm{Ba}^{2+}$ current experiments (Fig. 7), thus ruling out unspecific effect of the inhibitors on $\mathrm{Ca}^{2+}$ channels.

Interestingly, the direct cause of Ano1 opening is still in debate. Potential candidates are (i) an increase in intracellular $\mathrm{Ca}^{2+}$, an enhanced Ano1-Ca ${ }^{2+}$ sensitivity induced by plasma membrane depolarization, or still $\mathrm{Ca}^{2+}$-calmodulin dependence; the $\mathrm{Ca}^{2+}$ increase could be very localized in microdomains of excluded cytoplasmic volume and defined by the close association between restricted plasma membrane domain and the endoplasmic reticulum (ER) [36, 73], as Ano1 seems to tether the plasma membrane to the ER as shown in the interstitial cells of Cajal [80]; (ii) an ATP-dependent mechanism (as for example, phosphorylation, dephosphorylation) [55] or an unknown dependence on cytosolic ATP [73]; (iii) a dependence of Anol opening from the CFTR as Edlund et al. [21] suggested a direct interaction between Ano1 and the CFTR when the latter is open by the cAMP/PKA pathway. However, the expression level of Anol is far greater than that of the CFTR. Also, their experiments were all performed in the presence of forskolin or GLP-1, which was not the case in the present study. Finally, these authors hypothesized that CFTR/Ano1 mediates a $\mathrm{Cl}^{-}$influx during AP, i.e., when the $\mathrm{Cl}^{-}$electrochemical potential favors $\mathrm{Cl}^{-}$into the cytosol and eventually into the granules (via ClC-3 channel). In another setting, Kunzelmann and Mehta [37] also suggested that the CFTR may play a role in Ano1 opening. Although the link between CFTR and Ano1 remains to be defined, this suggestion is quite interesting as another recent study strongly implicated the CFTR chloride channel in the glucose-induced $\beta$ cell plasma membrane depolarization [26]. Thus, besides Ano1, the CFTR may also participate to the $\mathrm{Cl}^{-}$efflux current upon glucose stimulation as the latter increases cAMP production [58]. However, diabetes observed in cystic fibrosis is rather uncommon before the first decade [46], suggesting that CFTR is not of absolute necessity for GSIS but could represent a way to open Ano1 under some physiological conditions. Clearly, the question of how glucose triggers Ano1 opening is not solved, and among attractive useful candidates, some of the numerous TRP channels expressed in the rat $\beta$ cell [13] could also be raised as they depolarize the cell and often mediate $\mathrm{Ca}^{2+}$ influx. For instance, an increment of reactive oxygen species (ROS) production, as observed upon $16.7-\mathrm{mM}$ glucose stimulation of mouse or rat $\beta$-cells islets $[41,57]$, activated TRPM2 and increased $\left[\mathrm{Ca}^{2+}\right]_{\mathrm{i}}$ in INS-1E and human $\beta$-cells [3]. Furthermore, insulin secretion was impaired in TRPM $2^{-/-}$mice [74]. In addition, a decrease in glucose-induced $\mathrm{Ca}^{2+}$ oscillations responsible for a drastic reduction in insulin secretion was described in TRPM5 $5^{-/}$ mice [12].

As a final objective, we examined whether $\mathrm{HCO}_{3}{ }^{-}$can also exit through Ano1. Bicarbonate ion appears to play a role in insulin secretion as (1) its omission from the extracellular medium drastically reduces insulin secretion [29]; (2) its entry 
into the $\beta$-cell appears mediated by NBCe1-B $[27,53]$. This electrogenic $\mathrm{Na}^{+}-\mathrm{HCO}_{3}{ }^{-}$-cotransporter, expressed in rat and human islet $\beta$-cells $[27,71]$, carries the entry of one negative charge (stoichiometry: $1 \mathrm{Na}^{+} / 2 \mathrm{HCO}_{3}{ }^{-}$). Thus, $\mathrm{HCO}_{3}{ }^{-}$entry is facilitated when the cell depolarizes and also when cytoplasmic $\mathrm{Cl}^{-}$decreases, given that NBCe1-B has $\mathrm{Cl}^{-}$-binding motifs [69]; (3) its concentration depends on its production from glucose metabolism which generates $\mathrm{H}_{2} \mathrm{O}$ and $\mathrm{CO}_{2}$, partially converted into $\mathrm{HCO}_{3}{ }^{-}$and $\mathrm{H}^{+}$ions in the presence of mitochondrial type $\mathrm{V}$ carbonic anhydrase [68]. While the protons can probably recycle into the mitochondrial matrix or rapidly exit the $\beta$-cell through the sodium-proton exchanger NHE1, $\mathrm{HCO}_{3}{ }^{-}$first accumulates within the cytoplasm; hence, it contributes to its alkalinization $[18,72]$ and possibly to cell volume increase. Acetazolamide-induced inhibition of carbonic anhydrase also decreases insulin secretion in rat pancreatic islets $[54,68]$. Thus, upon glucose stimulation, intracellular $\mathrm{HCO}_{3}{ }^{-}$appears to increase from two different sources: metabolically generated from mitochondrial pyruvate oxidation and absorbed from the extracellular medium through NBCe1-B. When cytoplasmic $\mathrm{Cl}^{-}$is largely decreased as a result of its exit through Ano1, $\mathrm{HCO}_{3}{ }^{-}$which has been accumulated within the cytoplasm can also exit through Ano1, as this channel has been shown to be permeant to $\mathrm{HCO}_{3}{ }^{-}$[55]. When intracellular $\mathrm{Cl}^{-}$was decreased, in the presence of bumetanide and $16.7 \mathrm{mM}$ glucose, AP amplitude was reduced with repolarized AP peak. In these conditions, bumetanide prevented $\mathrm{Cl}^{-}$recycling; hence, Anol current mediated the exit of $\mathrm{HCO}_{3}{ }^{-}$. Acetazolamide which partially reduces intracellular $\mathrm{HCO}_{3}{ }^{-}$concentration decreased further AP amplitude and peak, in $\mathrm{HCO}_{3}{ }^{-}$-free media (Fig. 8). As shown by Sener et al. [68], acetazolamide also decreased GSIS in rat islets. Thus, glucose also appears to induce $\mathrm{HCO}_{3}^{-}$exit through Ano1.

Ano1 ${ }^{-/}$mice do not survive more than a few days unlike $\mathrm{Ano1}^{+/-}$mice which showed impaired insulin secretion [76]. This elegant study also completely supports a role for Ano1 in insulin secretion. The authors reported that insulin and Ano1 genes lie on the same human chromosome 11, that they interact with each other, and that this interaction is strengthened, upon glucose stimulation. Twenty-five-millimolar glucose induced a threefold increased expression of Ano1 after $1 \mathrm{~h}$, whereas its expression was decreased in the presence of siRNA against the insulin promoter.

Thus, the glucose-induced gating of Ano1 may be as important as the $\mathrm{K}_{\text {ATP }}^{+}$channel closure to induce $\beta$-cell depolarization. We further suggest that Anol cyclic gating is responsible for the oscillatory pattern of membrane potential upon glucose stimulation with alternating active phases with AP and partially repolarized silent phases. These are instrumental in generating $\mathrm{Ca}^{2+}{ }_{\mathrm{i}}$ oscillations and sustained insulin secretion. Blocking Ano1 nearly completely abolished the membrane potential oscillations as well as GSIS.
In conclusion, the present results demonstrate that in murine $\beta$-cells, glucose-induced opening of Ano1 is absolutely critical to reach the threshold potential for opening the L-type $\mathrm{Ca}^{2+}$ channels.

Acknowledgments We thank the "Fund Alphonse and Jean Forton" and "Fund Crawez" and the Belgian Foundation for Scientific Medical Research (grant 3.4520.07) for supporting this research, Emeline Hupkens and Fabienne Leleux for technical help in islet isolation and some insulin secretion experiments, Michèle Authelet for help in immunohistochemistry experiments, Prof. Caroline Verhoeven for help in statistical analysis, and Prof. David Gall for helpful suggestions.

Open Access This article is distributed under the terms of the Creative Commons Attribution 4.0 International License (http:// creativecommons.org/licenses/by/4.0/), which permits unrestricted use, distribution, and reproduction in any medium, provided you give appropriate credit to the original author(s) and the source, provide a link to the Creative Commons license, and indicate if changes were made.

\section{References}

1. Alshahrani S, Alvarez-Leefmans FJ, Di Fulvio M (2012) Expression of the Slc12a1 gene in pancreatic $\beta$-cells: molecular characterization and in silico analysis. Cell Physiol Biochem 30: 95-112. doi:10.1159/000339050, PMID: 22759959

2. Armstrong D, Eckert R (1987) Voltage-activated calcium channels that must be phosphorylated to respond to membrane depolarization. Proc Natl Acad Sci U S A 84:2518-2522, PMID: 2436233

3. Bari MR, Akbar S, Eweida M, Kühn FJ, Gustafsson AJ, Lückhoff A, Islam MS (2009) H2O2-induced Ca2+ influx and its inhibition by $\mathrm{N}$-(p-amylcinnamoyl) anthranilic acid in the beta-cells: involvement of TRPM2 channels. J Cell Mol Med 13:3260-3267. doi:10. 1111/j.1582-4934.2009.00737.x, PMID: 19382906

4. Bartos DC, Grandi E, Ripplinger CM (2015) Ion channels in the heart. Compr Physiol 5:1423-1464. doi:10.1002/cphy.c140069, PMID: 26140724

5. Beauvois MC, Merezak C, Jonas JC, Ravier MA, Henquin JC, Gilon P (2006) Glucose-induced mixed [Ca2+]c oscillations in mouse beta-cells are controlled by the membrane potential and the SERCA3 Ca2+ATPase of the endoplasmic reticulum. Am J Physiol Cell Physiol 290:1503-1511, PMID: 16381799

6. Belz M, Willenborg M, Görgler N, Hamada A, Schumacher K, Rustenbeck I (2014) Insulinotropic effect of high potassium concentration beyond plasma membrane depolarization. Am J Physiol Endocrinol Metab 306:697-706. doi:10.1152/ajpendo.00362.2013, PMID: 24452455

7. Bergsten P, Grapengiesser E, Gylfe E, Tengholm A, Hellman B (1994) Synchronous oscillations of cytoplasmic $\mathrm{Ca} 2+$ and insulin release in glucose-stimulated pancreatic islets. J Biol Chem 269: 8749-8753, PMID: 8132606

8. Best L, Brown PD (2009) Studies of the mechanism of activation of the volume-regulated anion channel in rat pancreatic beta-cells. $\mathrm{J}$ Membr Biol 230:83-91. doi:10.1007/s00232-009-9189-x, PMID: 19669073

9. Best L (2005) Glucose-induced electrical activity in rat pancreatic beta-cells: dependence on intracellular chloride concentration. J Physiol 568:137-144, PMID: 16024506

10. Braun M, Ramracheya R, Bengtsson M, Zhang Q, Karanauskaite J, Partridge C, Johnson PR, Rorsman P (2008) Voltage-gated ion channels in human pancreatic beta-cells: electrophysiological 
characterization and role in insulin secretion. Diabetes 57:16181628. doi:10.2337/db07-0991, PMID: 18390794

11. Cliff WH, Schoumacher RA, Frizzell RA (1992) cAMP-activated $\mathrm{Cl}$ channels in CFTR-transfected cystic fibrosis pancreatic epithelial cells. Am J Physiol 262:1154-1160, PMID: 1375432

12. Colsoul B, Schraenen A, Lemaire K, Quintens R, Van Lommel L, Segal A, Owsianik G, Talavera K, Voets T, Margolskee RF, Kokrashvili Z, Gilon P, Nilius B, Schuit FC, Vennekens R (2010) Loss of high-frequency glucose-induced $\mathrm{Ca} 2+$ oscillations in pancreatic islets correlates with impaired glucose tolerance in Trpm5-/ - mice. Proc Natl Acad Sci U S A 107:5208-5213. doi:10.1073/ pnas.0913107107, PMID: 20194741

13. Colsoul B, Vennekens R, Nilius B (2011) Transient receptor potential cation channels in pancreatic $\beta$ cells. Rev Physiol, Biochem Pharmacol 161:87-110. doi:10.1007/112_2011_2, PMID: 21744203

14. Davis AJ, Shi J, Pritchard HA, Chadha PS, Leblanc N, Vasilikostas G, Yao Z, Verkman AS, Albert AP, Greenwood IA (2013) Potent vasorelaxant activity of the TMEM16A inhibitor T16A(inh) -A01. Br J Pharmacol 168:773-784. doi:10.1111/j.1476-5381.2012. 02199.x, PMID: 22946562

15. Dean PM, Matthews EK (1970) Electrical activity in pancreatic islet cells: effect of ions. J Physiol 210:265-275, PMID: 5501260

16. Dean PM, Matthews EK (1968) Electrical activity in pancreatic islet cells. Nature 219:389-390, PMID: 4873864

17. Dean PM, Matthews EK (1970) Glucose-induced electrical activity in pancreatic islet cells. J Physiol 210:255-264, PMID: 5501259

18. Deleers M, Lebrun P, Malaisse WJ (1983) Increase in CO3H- influx and cellular $\mathrm{pH}$ in glucose-stimulated pancreatic islets. FEBS Lett 154:97-100, PMID: 6339276

19. Düfer M, Gier B, Wolpers D, Krippeit-Drews P, Ruth P, Drews G (2009) Enhanced glucose tolerance by SK4 channel inhibition in pancreatic beta-cells. Diabetes 58:1835-1843. doi:10.2337/db081324, PMID: 19401418

20. Eckford PD, Li C, Ramjeesingh M, Bear CE (2012) Cystic fibrosis transmembrane conductance regulator (CFTR) potentiator VX-770 (ivacaftor) opens the defective channel gate of mutant CFTR in a phosphorylation-dependent but ATP-independent manner. J Biol Chem 287:36639-36649. doi:10.1074/jbc.M112.393637, PMID: 22942289

21. Edlund A, Esguerra JL, Wendt A, Flodström-Tullberg M, Eliasson L (2014) CFTR and Anoctamin 1 (ANO1) contribute to cAMP amplified exocytosis and insulin secretion in human and murine pancreatic beta-cells. BMC Med 12:87. doi:10.1186/1741-701512-87, PMID: 24885604

22. Evans MG, Marty A (1986) Calcium-dependent chloride currents in isolated cells from rat lacrimal glands. J Physiol 378:437-460, PMID: 2432252

23. Faria D, Rock JR, Romao AM, Schweda F, Bandulik S, Witzgall R, Schlatter E, Heitzmann D, Pavenstädt H, Herrmann E, Kunzelmann K, Schreiber R (2014) The calcium-activated chloride channel Anoctamin 1 contributes to the regulation of renal function. Kidney Int 85:1369-1381. doi:10.1038/ki.2013.535, PMID: $\mathbf{2 4 4 7 6 6 9 4}$

24. Gilon P, Shepherd RM, Henquin JC (1993) Oscillations of secretion driven by oscillations of cytoplasmic $\mathrm{Ca} 2+$ as evidences in single pancreatic islets. J Biol Chem 268:22265-22268, PMID: 8226733

25. Göpel SO, Kanno T, Barg S, Eliasson L, Galvanovskis J, Renström E, Rorsman P (1999) Activation of $\mathrm{Ca}(2+)$-dependent $\mathrm{K}(+)$ channels contributes to rhythmic firing of action potentials in mouse pancreatic beta cells. J Gen Physiol 114:759-770, PMID: $\mathbf{1 0 5 7 8 0 1 3}$

26. Guo JH, Chen H, Ruan YC, Zhang XL, Zhang XH, Fok KL, Tsang LL, Yu MK, Huang WQ, Sun X, Chung YW, Jiang X, Sohma Y, Chan HC (2014) Glucose-induced electrical activities and insulin secretion in pancreatic islet $\beta$-cells are modulated by CFTR. Nat Commun 5:4420. doi:10.1038/ncomms5420, PMID: 25025956

27. Hanzu FA, Gasa R, Bulur N, Lybaert P, Gomis R, Malaisse WJ, Beauwens R, Sener A (2012) Expression of TMEM16A and SLC4A4 in human pancreatic islets. Cell Physiol Biochem 29:6164. doi:10.1159/000337587, PMID: 22415075

28. Henquin JC (1998) A minimum of fuel is necessary for tolbutamide to mimic the effects of glucose on electrical activity in pancreatic beta-cells. Endocrinology 139:993-998, PMID: 9492030

29. Henquin JC, Lambert AE (1975) Extracellular bicarbonate ions and insulin secretion. Biochim Biophys Acta 381:437-442, PMID: 1089433

30. Henquin JC, Meissner HP (1984) Significance of ionic fluxes and changes in membrane potential for stimulus-secretion coupling in pancreatic B-cells. Experientia 40:1043-1052, PMID: 6386515

31. Henquin JC, Meissner HP, Schmeer W (1982) Cyclic variations of glucose-induced electrical activity in pancreatic B cells. Pflugers Arch 393:322-327, PMID: 6750552

32. Herchuelz A, Thonnart N, Sener A, Malaisse WJ (1980) Regulation of calcium fluxes in pancreatic islets: the role of membrane depolarization. Endocrinology 107:491-497, PMID: 6993189

33. Herrington J, Zhou YP, Bugianesi RM, Dulski PM, Feng Y, Warren VA, Smith MM, Kohler MG, Garsky VM, Sanchez M, Wagner M, Raphaelli K, Banerjee P, Ahaghotu C, Wunderler D, Priest BT, Mehl JT, Garcia ML, McManus OB, Kaczorowski GJ, Slaughter RS (2006) Blockers of the delayed-rectifier potassium current in pancreatic beta-cells enhance glucose-dependent insulin secretion. Diabetes 55:1034-1042, Erratum in: Diabetes 55:1904 (2006)

34. Houamed KM, Sweet IR, Satin LS (2010) BK channels mediate a novel ionic mechanism that regulates glucose-dependent electrical activity and insulin secretion in mouse pancreatic $\beta$-cells. J Physiol 588:3511-3523. doi:10.1113/jphysiol.2009.184341, PMID: 20643769

35. Hwang SJ, Blair PJ, Britton FC, O'Driscoll KE, Hennig G, Bayguinov YR, Rock JR, Harfe BD, Sanders KM, Ward SM (2009) Expression of anoctamin 1/TMEM16A by interstitial cells of Cajal is fundamental for slow wave activity in gastrointestinal muscles. J Physiol 587:4887-4904. doi:10.1113/jphysiol.2009. 176198, PMID: 19687122

36. Jin X, Shah S, Du X, Zhang H, Gamper N (2014) Activation of $\mathrm{Ca}(2+)$-activated $\mathrm{Cl}(-)$ channel $\mathrm{ANO} 1$ by localized $\mathrm{Ca}(2+)$ signals. J Physiol 0:1-12. doi:10.1113/jphysiol.2014.275107, PMID: 25398532

37. Kunzelmann K, Mehta A (2013) CFTR: a hub for kinases and crosstalk of cAMP and Ca2+. FEBS J 280:4417-4429. doi:10. 1111/febs.12457, PMID: 23895508

38. Kunzelmann K (2015) TMEM16, LRRC8A, bestrophin: chloride channels controlled by $\mathrm{Ca}(2+)$ and cell volume. Trends Biochem Sci 40:535-543. doi:10.1016/j.tibs.2015.07.005, PMID: 26254230

39. Kuruma A, Hartzell HC (2000) Bimodal control of a Ca(2+)-activated $\mathrm{Cl}(-)$ channel by different $\mathrm{Ca}(2+)$ signals. J Gen Physiol 115: 59-80, PMID:10613919

40. Leclercq-Meyer V, Marchand J, Woussen-Colle MC, Malaisse WJ (1985) Multiple effects of leucine on glucagon, insulin and somatostatin secretion from the perfused rat pancreas. Endocrinology 116: 1168-1174, PMID: 2857640

41. Leloup C, Tourrel-Cuzin C, Magnan C, Karaca M, Castel J, Carneiro L, Colombani AL, Ktorza A, Casteilla L, Pénicaud L (2009) Mitochondrial reactive oxygen species are obligatory signals for glucose-induced insulin secretion. Diabetes 58:673-681. doi:10.2337/db07-1056, PMID: 19073765

42. Malaisse-Lagae F, Malaisse WJ (1984) Insulin release by pancreatic islets. In: Larner J, Pohl SL (eds) Methods in diabetes research, 1st edn. Wiley, New York, pp 147-152 
43. Malaisse WJ, Zhang Y, Louchami K, Jijakli H (2004) Stimulation by D-glucose of 36Cl-efflux from prelabeled rat pancreatic islets. Endocrine 25:23-25, PMID: 15545702

44. Mariot P, Gilon P, Nenquin M, Henquin JC (1998) Tolbutamide and diazoxide influence insulin secretion by changing the concentration but not the action of cytoplasmic Ca2+ in beta-cells. Diabetes 47: 365-373, PMID: 9519741

45. Markadieu N, Crutzen R, Boom A, Erneux C, Beauwens R (2009) Inhibition of insulin-stimulated hydrogen peroxide production prevents stimulation of sodium transport in A6 cell monolayers. Am J Physiol Renal Physiol 296:1428-1438. doi:10.1152/ajprenal. 90397.2008, PMID: 19297450

46. Moran A, Dunitz J, Nathan B, Saeed A, Holme B, Thomas W (2009) Cystic fibrosis-related diabetes: current trends in prevalence, incidence, and mortality. Diabetes Care 32:1626-1631. doi:10. 2337/dc09-0586, PMID: 19542209

47. Namkung W, Phuan PW, Verkman AS (2011) TMEM16A inhibitors reveal TMEM16A as a minor component of calcium-activated chloride channel conductance in airway and intestinal epithelial cells. J Biol Chem 286:2365-2374. doi:10.1074/jbc.M110. 175109, PMID: 21084298

48. Namkung W, Thiagarajah JR, Phuan PW, Verkman AS (2010) Inhibition of $\mathrm{Ca} 2+-$ activated $\mathrm{Cl}$ - channels by gallotannins as a possible molecular basis for health benefits of red wine and green tea. FASEB J 24:4178-4186. doi:10.1096/fj.10-160648, PMID: 20581223

49. Nilius B, Prenen J, Szücs G, Wei L, Tanzi F, Voets T, Droogmans G (1997) Calcium-activated chloride channels in bovine pulmonary artery endothelial cells. J Physiol 498:381-396, PMID: 9032686

50. Nilius B, Prenen J, Voets T, Van den Bremt K, Eggermont J, Droogmans G (1997) Kinetic and pharmacological properties of the calcium-activated chloride-current in macrovascular endothelial cells. Cell Calcium 22:53-63, PMID: 9232352

51. Ohta M, Nelson D, Wilson JM, Meglasson MD, Erecińska M (1992) Relationships between energy level and insulin secretion in isolated rat islets of Langerhans. Manipulation of [ATP]/ [ADP][Pi] by 2-deoxy-D-glucose. Biochem Pharmacol 43:18591864, PMID: 1575778

52. Ohta M, Nelson J, Nelson D, Meglasson MD, Erecińska M (1993) Effect of $\mathrm{Ca}++$ channel blockers on energy level and stimulated insulin secretion in isolated rat islets of Langerhans. J Pharmacol Exp Ther 264:35-40, PMID: 8423537

53. Parker MD, Boron WF (2013) The divergence, actions, roles, and relatives of sodium-coupled bicarbonate transporters. Physiol Rev 93:803-959. doi:10.1152/physrev.00023.2012, PMID: 2358983

54. Parkkila AK, Scarim AL, Parkkila S, Waheed A, Corbett JA, Sly WS (1998) Expression of carbonic anhydrase V in pancreatic beta cells suggests role for mitochondrial carbonic anhydrase in insulin secretion. J Biol Chem 273:24620-24623, PMID: 9733757

55. Pedemonte N, Galietta LJ (2014) Structure and function of TMEM16 proteins (anoctamins). Physiol Rev 94:419-459. doi: 10.1152/physrev.00039.2011, PMID: 24692353

56. Pfeiffer T, Kraushaar U, Düfer M, Schönecker S, Haspel D, Günther E, Drews G, Krippeit-Drews P (2011) Rapid functional evaluation of beta-cells by extracellular recording of membrane potential oscillations with microelectrode arrays. Pflugers Arch 462:835-840. doi:10.1007/s00424-011-1029-z, PMID: 21947556

57. Pi J, Bai Y, Zhang Q, Wong V, Floering LM, Daniel K, Reece JM, Deeney JT, Andersen ME, Corkey BE, Collins S (2007) Reactive oxygen species as a signal in glucose-stimulated insulin secretion. Diabetes 56:1783-1791, PMID: 17400930

58. Ramos LS, Zippin JH, Kamenetsky M, Buck J, Levin LR (2008) Glucose and GLP-1stimulate cAMP production via distinct adenylyl cyclases in INS-1E insulinoma cells. J Gen Physiol 132: 329-338. doi:10.1085/jgp.200810044, PMID: 18695009
59. Rorsman P, Ammälä C, Berggren PO, Bokvist K, Larsson O (1992) Cytoplasmic calcium transients due to single action potentials and voltage-clamp depolarizations in mouse pancreatic B-cells. EMBO J 11:2877-2884, PMID: 1639061

60. Rorsman P, Ashcroft FM, Trube G (1988) Single Ca channel currents in mouse pancreatic B-cells. Pflugers Arch 412:597-603, PMID: 2463514

61. Santos RM, Rosario LM, Nadal A, Garcia-Sancho J, Soria B, Valdeolmillos M (1991) Widespread synchronous [Ca2+]i oscillations due to bursting electrical activity in single pancreatic islets. Pflugers Arch 418:417-422, PMID: 1876486

62. Sato Y, Anello M, Henquin JC (1999) Glucose regulation of insulin secretion independent of the opening or closure of adenosine triphosphate-sensitive K+ channels in beta cells. Endocrinology 140:2252-2257, PMID: 10218978

63. Schreiber R, Uliyakina I, Kongsuphol P, Warth R, Mirza M, Martins JR, Kunzelmann K (2010) Expression and function of epithelial anoctamins. J Biol Chem 285:7838-7845. doi:10.1074/ jbc.M109.065367, PMID: 20056604

64. Schroeder BC, Cheng T, Jan YN, Jan LY (2008) Expression cloning of TMEM16A as a calcium-activated chloride channel subunit. Cell 134:1019-1029. doi:10.1016/j.cell.2008.09.003, PMID: 18805094

65. Sehlin J (1987) Evidence for voltage-dependent Cl- permeability in mouse pancreatic beta-cells. Biosci Rep 7:67-72, PMID: 2441772

66. Sehlin J (1978) Interrelationship between chloride fluxes in pancreatic islets and insulin release. Am J Physiol 235:E501-E508, PMID: 31793

67. Sehlin J, Meissner HP (1988) Effects of Cl- deficiency on the membrane potential in mouse pancreatic beta-cells. Biochim Biophys Acta 937:309-318, PMID: 3276351

68. Sener A, Jijakli H, Zahedi Asl S, Courtois P, Yates AP, Meuris S, Best LC, Malaisse WJ (2007) Possible role of carbonic anhydrase in rat pancreatic islets: enzymatic, secretory, metabolic, ionic, and electrical aspects. Am J Physiol Endocrinol Metab 292:1624-1630, PMID: 17284575

69. Shcheynikov N, Son A, Hong JH, Yamazaki O, Ohana E, Kurtz I, Shin DM, Muallem S (2015) Intracellular Cl- as a signaling ion that potently regulates $\mathrm{Na}+/ \mathrm{HCO} 3$ - transporters. Proc Natl Acad Sci U S A 112:329-337. doi:10.1073/pnas.1415673112, PMID: 25561556

70. Shlyonsky V, Goolaerts A, Mies F, Naeije R (2008) Electrophysiological characterization of rat type II pneumocytes in situ. Am J Respir Cell Mol Biol 39:36-44. doi:10.1165/rcmb. 2007-0227OC, PMID: 18276797

71. Soyfoo MS, Bulur N, Virreira M, Louchami K, Lybaert P, Crutzen R, Perret J, Delporte C, Roussa E, Thevenod F, Best L, Yates AP, Malaisse WJ, Sener A, Beauwens R (2009) Expression of the electrogenic $\mathrm{Na}+-\mathrm{HCO} 3-$ cotransporters NBCe1-A and NBCe1-B in rat pancreatic islet cells. Endocrine 35:449-458. doi:10.1007/ s12020-009-9175-1, PMID: 19381888

72. Stiernet P, Nenquin M, Moulin P, Jonas JC, Henquin JC (2007) Glucose-induced cytosolic $\mathrm{pH}$ changes in beta-cells and insulin secretion are not causally related: studies in islets lacking the $\mathrm{Na}+\mathrm{H}+$ exchanger NHE1. J Biol Chem 282:24538-24546, PMID: 17599909

73. Tian Y, Kongsuphol P, Hug M, Ousingsawat J, Witzgall R, Schreiber R, Kunzelmann K (2011) Calmodulin-dependent activation of the epithelial calcium-dependent chloride channel TMEM16A. FASEB J 25:1058-1068. doi:10.1096/fj.10-166884, PMID: 21115851

74. Uchida K, Dezaki K, Damdindorj B, Inada H, Shiuchi T, Mori Y, Yada T, Minokoshi Y, Tominaga M (2011) Lack of TRPM2 impaired insulin secretion and glucose metabolisms in mice. Diabetes 60:119-126. doi:10.2337/db10-0276, PMID: 20921208

75. Wanitchakool P, Wolf L, Koehl GE, Sirianant L, Schreiber R, Kulkarni S, Duvvuri U, Kunzelmann K (2014) Role of anoctamins 
in cancer and apoptosis. Philos Trans R Soc Lond B Biol Sci 369: 20130096. doi:10.1098/rstb.2013.0096, PMID: 24493744

76. Xu Z, Lefevre GM, Gavrilova O, Foster St Claire MB, Riddick G, Felsenfeld G (2014) Mapping of long-range INS promoter interactions reveals a role for calcium-activated chloride channel ANO1 in insulin secretion. Proc Natl Acad Sci U S A 111:16760-16765. doi: 10.1073/pnas.1419240111, PMID: 25385647

77. Yang SN, Berggren PO (2005) Beta-cell CaV channel regulation in physiology and pathophysiology. Am J Physiol Endocrinol Metab 288:16-28, PMID: 15585596

78. Yang YD, Cho H, Koo JY, Tak MH, Cho Y, Shim WS, Park SP, Lee J, Lee B, Kim BM, Raouf R, Shin YK, Oh U (2008) TMEM16A confers receptor-activated calcium-dependent chloride conductance. Nature 455:1210-1215. doi:10.1038/nature07313, PMID: 18724360
79. Zhu MH, Kim TW, Ro S, Yan W, Ward SM, Koh SD, Sanders KM (2009) A Ca(2+)-activated $\mathrm{Cl}(-)$ conductance in interstitial cells of Cajal linked to slow wave currents and pacemaker activity. J Physiol 587:4905-4918. doi:10.1113/jphysiol.2009.176206, PMID: 19703958

80. Zhu MH, Sung TS, O’Driscoll K, Koh SD, Sanders KM (2015) Intracellular $\mathrm{Ca}(2+)$ release from endoplasmic reticulum regulates slow wave currents and pacemaker activity of interstitial cells of Cajal. Am J Physiol Cell Physiol 308:C608-C620. doi:10.1152/ ajpcell.00360.2014, PMID: 25631870

81. Zimliki CL, Chenault VM, Mears D (2009) Glucose-dependent and -independent electrical activity in islets of Langerhans of Psammomys obesus, an animal model of nutritionally induced obesity and diabetes. Gen Comp Endocrinol 161:193-201. doi:10. 1016/j.ygcen.2008.12.017, PMID: 19167400 